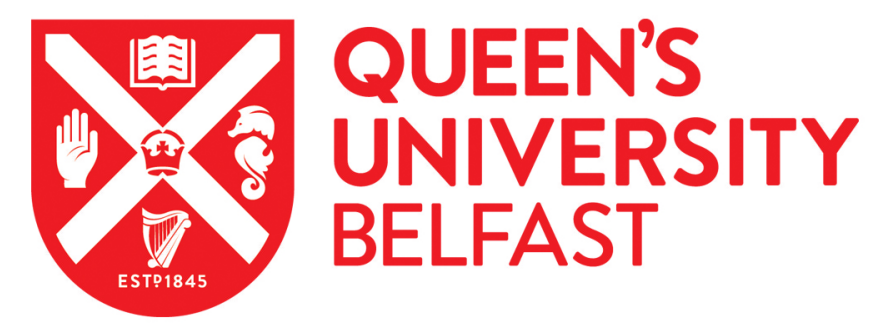

\title{
High Pressure Speed of Sound and Related Thermodynamic Properties of 1-Alkyl-3-methylimidazolium Bis[(trifluoromethyl)sulfonyl]imides (from 1-Propyl- to 1-Hexyl-)
}

Skowronek, J., Dzida, M., Zorebski, E., Chorążewski, M., Jezak, S., Żarska, M., Zorębski, M., Goodrich, P., \& Jacquemin, J. (2016). High Pressure Speed of Sound and Related Thermodynamic Properties of 1-Alkyl-3methylimidazolium Bis[(trifluoromethyl)sulfonyl]imides (from 1-Propyl- to 1-Hexyl-). Journal of Chemical and Engineering Data. https://doi.org/10.1021/acs.jced.6b00413

Published in:

Journal of Chemical and Engineering Data

Document Version:

Peer reviewed version

Queen's University Belfast - Research Portal:

Link to publication record in Queen's University Belfast Research Portal

Publisher rights

Copyright 2016 ACS.

\section{General rights}

Copyright for the publications made accessible via the Queen's University Belfast Research Portal is retained by the author(s) and / or other copyright owners and it is a condition of accessing these publications that users recognise and abide by the legal requirements associated with these rights.

Take down policy

The Research Portal is Queen's institutional repository that provides access to Queen's research output. Every effort has been made to ensure that content in the Research Portal does not infringe any person's rights, or applicable UK laws. If you discover content in the

Research Portal that you believe breaches copyright or violates any law, please contact openaccess@qub.ac.uk. 


\section{High Pressure Speed of Sound and Related Thermodynamic Properties of 1-Alkyl-3-Methylimidazolium Bis[(trifluoromethyl)sulfonyl]imides (from 1-propyl- to 1-hexyl-)}

Justyna Skowronek ${ }^{1}$, Marzena Dzida ${ }^{1 *}$, Edward Zorebski ${ }^{1}$, Mirosław Chorążewski ${ }^{1}$, Sylwia Jezak $^{1}$, Monika Żarska ${ }^{1}$, Michał Zorębski ${ }^{1}$, Peter Goodrich² ${ }^{2}$ Johan Jacquemin ${ }^{2}$

${ }^{1}$ University of Silesia, Institute of Chemistry, Szkolna 9, 40-006 Katowice, Poland

${ }^{2}$ School of Chemistry and Chemical Engineering/QUILL Research Centre, Queen's University of Belfast, David Keir Building, Belfast BT9 5AG, Northern Ireland, UK

${ }^{3}$ Université François Rabelais, Laboratoire PCM2E, Parc de Grandmont 37200 Tours, France Corresponding author: ${ }^{*}$ Marzena Dzida: e-mail: mhd@ich.us.edu.pl

\section{ABSTRACT:}

The knowledge of thermodynamic high-pressure speed of sound in ionic liquids (ILs) is a crucial way either to study the nature of the molecular interactions, structure and packing effects or to determine other key thermodynamic properties of ILs essential for their applications in any chemical and industrial processes. Herein, we report the speed of sound as a function temperature at pressures up to $101 \mathrm{MPa}$ in four ultrapure ILs: 1-propyl-3methylimidazolium bis[(trifluoromethyl)sulfonyl]imide, 1-butyl-3-methylimidazolium bis[(trifluoromethyl)sulfonyl]imide, 1-pentyl-3-methylimidazolium bis[(trifluoromethyl)sulfo nyl]imide, and 1-hexyl-3-methylimidazolium bis[(trifluoromethyl)sulfonyl]imide, taking into consideration their relaxation behavior. Additionally, to further improve the reliability of the speed of sound results, the density, isentropic compressibility and isobaric heat capacity as a function of temperature and pressure are calculated using an acoustic method. 
Keywords: ionic liquids; speed of sound; density; isentropic compressibility; isobaric heat capacity; high pressure

\section{INTRODUCTION}

High-pressure thermodynamic properties of fluids are of considerable interest from a fundamental and a practical point of view. Their knowledge helps us to better understand type and nature of the molecular interactions, thus enabling the development of adequate models of the liquid state. In general, the high-pressure data help in developing technologies that require working liquids exposed to changing pressure, e.g. those of fuels, hydraulic fluids, refrigerants, cleaning and foaming agents, etc. Furthermore, from a fundamental point of view, the speed of sound is one of the key quantities for the equation of state development. ${ }^{1-3}$ The acoustic method, which has found widespread acceptance as a precise tool for the determination of thermodynamic properties of compressed liquids, is an excellent alternative to the direct determination of the $p-\rho-T$ data of liquids. These data obtained from the experimental speeds of sound are not only considered reliable but also versatile because the speed of sound can be measured accurately over wide ranges of temperature and pressure..$^{4-6}$ As the propagation of sound waves is an adiabatic process, the acoustic method can be used for determining the isentropic compressibility of fluids directly. Combining the isentropic compressibility along with the isobaric heat capacity, the isothermal compressibility can then be calculated. Additionally, the isochoric heat capacity and internal pressure can also be determined using isothermal and isentropic compressibility data. Knowledge of these thermophysical properties over a sufficiently wide range of temperatures and pressures for various ILs could undoubtedly facilitate the correlation of their properties to further evaluate their real potential for industrial and large-scale engineering applications. However, the interpretation of speed of sound data and their usability for the determination of related thermodynamic properties is only possible on the basis of the prior knowledge of the 
relaxation regions. Observed ultrasound absorption spectra of some ILs suggest that under high-pressure and/or low temperature a dependence of ultrasound velocity on frequency may be observed at frequencies of transducers operating in conventional and commercial ultrasound devices. ${ }^{7}$ In that case, the measured values cannot be regarded as the thermodynamic speed of sound; thus it is not possible to use the Newton-Laplace equation and to determine other thermodynamic properties.

Up to date, experimental high-pressure speed of sound data were reported in six pure ILs, namely the 1-ethyl-3-methylimidazolium bis[(trifluoromethyl)sulfonyl]imide, ${ }^{8}$ 1-propyl-3methylimidazolium $\quad$ bis[(trifluoromethyl)sulfonyl $]$ imide, ${ }^{9} \quad$ 1-butyl-3-methylimidazolium bis[(trifluoromethyl)sulfonyl]imide, ${ }^{10}$ 1-pentyl-3-methylimidazolium $\quad$ bis[(trifluoromethyl) sulfonyl]imide, ${ }^{9}$ 1-butyl-3-methylimidazolium hexafluorophosphate, ${ }^{11}$ and 1-butyl-3methylimidazolium tetrafluoroborate ${ }^{11}$ (abbreviations: [ $\left.\mathrm{C}_{2} \mathrm{C}_{1} \mathrm{im}\right]\left[\mathrm{NTf}_{2}\right], \quad\left[\mathrm{C}_{3} \mathrm{C}_{1} \mathrm{im}\right]\left[\mathrm{NTf}_{2}\right]$, $\left[\mathrm{C}_{4} \mathrm{C}_{1} \mathrm{im}\right]\left[\mathrm{NTf}_{2}\right],\left[\mathrm{C}_{5} \mathrm{C}_{1} \mathrm{im}\right]\left[\mathrm{NTf}_{2}\right],\left[\mathrm{C}_{4} \mathrm{C}_{1} \mathrm{im}\right]\left[\mathrm{PF}_{6}\right]$ and $\left[\mathrm{C}_{4} \mathrm{C}_{1} \mathrm{im}\right]\left[\mathrm{BF}_{4}\right]$, respectively). The speed of sound measurements in $\left[\mathrm{C}_{2} \mathrm{C}_{1} \mathrm{im}\right]\left[\mathrm{NTf}_{2}\right]$ were performed in the temperature range from $288.15 \mathrm{~K}$ to $318.15 \mathrm{~K}$ and at pressures from $15 \mathrm{MPa}$ to $101 \mathrm{MPa} .^{8}$ The speed of sound in $\left[\mathrm{C}_{3} \mathrm{C}_{1} \mathrm{im}\right]\left[\mathrm{NTf}_{2}\right]$ in the temperature range from $298.15 \mathrm{~K}$ to $338.15 \mathrm{~K}$ at pressures up to 200 $\mathrm{MPa}$ and in $\left[\mathrm{C}_{5} \mathrm{C}_{1} \mathrm{im}\right]\left[\mathrm{NTf}_{2}\right]$ in the temperature range from $288.15 \mathrm{~K}$ to $338.15 \mathrm{~K}$ at pressures up to $200 \mathrm{MPa}$ have been previously reported by Esperança et al. ${ }^{9}$ Gomes de Azevedo et al. ${ }^{10,11}$ have reported speed of sound data in $\left[\mathrm{C}_{4} \mathrm{C}_{1} \mathrm{im}\right]\left[\mathrm{NTf}_{2}\right]^{10}$ and $\left[\mathrm{C}_{4} \mathrm{C}_{1} \mathrm{im}\right]\left[\mathrm{PF}_{6}\right]^{11}$ at temperatures from $283.15 \mathrm{~K}$ to $323 \mathrm{~K}$ at pressures up to $151 \mathrm{MPa}$ and in $\left[\mathrm{C}_{4} \mathrm{C}_{1} \mathrm{im}\right]\left[\mathrm{BF}_{4}\right]^{11}$ in the same temperature range at pressures up to $160 \mathrm{MPa}$. Additionally, $p-\rho-T$ data of $\left[\mathrm{C}_{4} \mathrm{C}_{1} \mathrm{im}\right]\left[\mathrm{NTf}_{2}\right]^{12}, \quad$ 1-hexyl-3-methylimidazolium $\quad$ bis[(trifluoromethyl)sulfonyl]imide $\left[\mathrm{C}_{6} \mathrm{C}_{1} \mathrm{im}\right]\left[\mathrm{NTf}_{2}\right]^{13}$, and 1-butyl-3-methylimidazolium acetate $\left[\mathrm{C}_{4} \mathrm{C}_{1} \mathrm{im}\right][\mathrm{OAc}]^{14}$ have also been used to calculate the speed of sound as a function of temperature and pressure $u(p, T)$. Speed of sound data were also estimated thanks to the $p-\rho$-T data using the SAFT-BACK equation of 
state for $\left[\mathrm{C}_{4} \mathrm{C}_{1} \mathrm{im}\right]\left[\mathrm{NTf}_{2}\right]^{15,16}$ and for all ILs for which experimental $u(p, T)$ data were available by Maghari et al. ${ }^{15}$ as well as for $\left[\mathrm{C}_{3} \mathrm{C}_{1} \mathrm{im}\right]\left[\mathrm{NTf}_{2}\right],\left[\mathrm{C}_{4} \mathrm{C}_{1} \mathrm{im}\right]\left[\mathrm{NTf}_{2}\right],\left[\mathrm{C}_{5} \mathrm{C}_{1} \mathrm{im}\right]\left[\mathrm{NTf}_{2}\right]$, $\left[\mathrm{C}_{4} \mathrm{C}_{1} \mathrm{im}\right]\left[\mathrm{PF}_{6}\right] .{ }^{17}$ As a result of the IUPAC Project 2002-005-1-100, [C $\left.{ }_{6} \mathrm{C}_{1} \mathrm{im}\right]\left[\mathrm{NTf}_{2}\right]$ was selected as an IUPAC reference sample for the thermodynamic, transport, and phase equilibrium properties. ${ }^{18,19}$ However, the speed of sound under high-pressure was not included in this investigation. To the best of our knowledge experimental high-pressure speeds of sound in $\left[\mathrm{C}_{6} \mathrm{C}_{1} \mathrm{im}\right]\left[\mathrm{NTf}_{2}\right]$ have never been reported in the open literature, to date. The main objective of this work is to study the effect of pressure and temperature on the speed of sound in 1-alkyl-3-methylimidazolium bis[(trifluoromethyl)sulfonyl]imides (from 1-propyl- to 1hexyl-) ([ $\left.\mathrm{C}_{n} \mathrm{C}_{1} \mathrm{im}\right]\left[\mathrm{NTf}_{2}\right]$ ) taking into consideration their relaxation behavior. To complete the speed of sound dataset for the $\left[\mathrm{C}_{n} \mathrm{C}_{1} \mathrm{im}\right]\left[\mathrm{NTf}_{2}\right]$ series, high-pressure speed of sound data in $\left[\mathrm{C}_{2} \mathrm{C}_{1} \mathrm{im}\right]\left[\mathrm{NTf}_{2}\right]$ reported by our group previously, ${ }^{8}$ were used as no other data are currently available in the literature. Our group already highlighted the accuracy of this dataset by comparing $\left[\mathrm{C}_{2} \mathrm{C}_{1} \mathrm{im}\right]\left[\mathrm{NTf}_{2}\right] p-\rho-T$ data using an indirect acoustic method with experimental $p$ $\rho-T$ data from the literature. ${ }^{8}$ In this work density, isentropic compressibility and isobaric heat capacity data as the function of the temperature and pressure were calculated using the acoustic method to compare the reliability of our data with literature $p-\rho-T$ and additionally $p-C_{p}-T$ data for $\left[\mathrm{C}_{n} \mathrm{C}_{1} \mathrm{im}\right]\left[\mathrm{NTf}_{2}\right]$ series under investigation.

\section{EXPERIMENTAL}

\section{Chemicals.}

$\left[\mathrm{C}_{3} \mathrm{C}_{1} \mathrm{im}\right]\left[\mathrm{NTf}_{2}\right],\left[\mathrm{C}_{4} \mathrm{C}_{1} \mathrm{im}\right]\left[\mathrm{NTf}_{2}\right],\left[\mathrm{C}_{5} \mathrm{C}_{1} \mathrm{im}\right]\left[\mathrm{NTf}_{2}\right],\left[\mathrm{C}_{6} \mathrm{C}_{1} \mathrm{im}\right]\left[\mathrm{NTf}_{2}\right]$ were synthesized and purified at the QUILL Centre, Belfast. The liquids were stored under argon, and the water content $(<200$ ppm) was determined by Karl Fischer titration. The halide content was undeterminable by $\mathrm{Ag}\left[\mathrm{NO}_{3}\right]$ testing below the limit. Specification of chemicals is presented in 
Table 1. Details about the synthesis, purification, and storage were presented in a previous paper. ${ }^{7}$ Additionally, we have measured the water content and density of $\left[\mathrm{C}_{6} \mathrm{C}_{1} \mathrm{im}\right]\left[\mathrm{NTf}_{2}\right]$ after filling the high-pressure system (139 ppm and $1371.79 \mathrm{~kg} \cdot \mathrm{m}^{-3}$ at $298.15 \mathrm{~K}$ ) and after highpressure speed of sound measurements (230 ppm and $1371.59 \mathrm{~kg} \cdot \mathrm{m}^{-3}$ at $298.15 \mathrm{~K}$ ).

\section{Speed of sound measurements.}

The speed of sound under high-pressure was measured at a frequency of $2 \mathrm{MHz}$ by means of the pulse-echo-overlap instrument, which was designed and constructed in our laboratory. ${ }^{5,20}$ The pressure was measured using a manometer consisting of a strain gauge HottingerBaldwin P3MB, equipped with a Hottinger-Baldwin MC3 signal amplifier, modified in our laboratory, and a digital voltmeter Meratronik V 542.1. The pressure was stabilized within $\pm 0.03 \mathrm{MPa}$ and measured with an uncertainty of less than $0.15 \%$. The temperature was measured using an Ertco Hart 850 platinum resistance thermometer (traceable to a NIST standard) with an uncertainty of $0.05 \mathrm{~K}$ and resolution of $0.001 \mathrm{~K}$. During the measurements, the temperature is stabilized within $\pm 0.01 \mathrm{~K}$ by a Haake DC 30 temperature controller. Double distilled water, degassed by boiling just before measurements, was used as the standard liquid for determining the ultrasonic path length. The specific conductivity of water was $1 \cdot 10^{-4} \mathrm{~S} \cdot \mathrm{m}^{-1}$. The values of the speed of sound in water under high-pressure were calculated using the IAPWS formulation. ${ }^{21}$

The repeatability of the measured speeds of sound was within less than $\pm 0.04 \%$ under highpressure. The expanded uncertainty ( $k=2$, level of confidence of 0.95$)$ under high-pressure for measured ILs was estimated to be less than $1 \mathrm{~m} \cdot \mathrm{s}^{-1} .8$

\section{Density measurements.}

The density at ambient pressure was measured by means of an Anton Paar vibrating tube densimeter (DMA 5000). All measurements were made in the static mode. The effect of the 
viscosity was also corrected. The densimeter was calibrated with air and double distilled water. The water of specific conductivity as above was degassed by boiling just before the measurements. Additionally the temperature range adjustment was performed. The density of the ILs was measured with an expanded uncertainty ( $k=2$, level of confidence of 0.95$)$ of less than $1 \cdot 10^{-1} \mathrm{~kg} \cdot \mathrm{m}^{-3}$ and a repeatability of less than $\pm 5 \cdot 10^{-3} \mathrm{~kg} \cdot \mathrm{m}^{-3}$.

\section{RESULTS AND DISCUSSION}

\section{High-pressure speed of sound.}

The speed of sound in each sample was systematically measured at a frequency of $2 \mathrm{MHz}$ as the function of the pressure up to $101 \mathrm{MPa}$; however, each temperature range has been carefully selected by taking into account the relaxation process in each investigated IL, reported in the previous works ${ }^{7,22}$ It was found that the $\left[\mathrm{C}_{2} \mathrm{C}_{1} \mathrm{im}\right]\left[\mathrm{NTf}_{2}\right]$ shows ultrasound velocity dispersion beginning in the vicinity of $78 \mathrm{MHz}$ at $293.15 \mathrm{~K}$ under atmospheric pressure, ${ }^{7,22}$ whereas for the $\left[\mathrm{C}_{6} \mathrm{C}_{1} \mathrm{im}\right]\left[\mathrm{NTf}_{2}\right]$ this phenomena appears above $28 \mathrm{MHz}$ at the same temperature. ${ }^{7,22}$ However, with increasing temperature the dispersion region is shifted towards higher frequencies (i.e., above $44 \mathrm{MHz}$ at $303.15 \mathrm{~K}$ and above $100 \mathrm{MHz}$ at 323.15 $\mathrm{K})^{7}$. Because of the close similarity of behavior of ILs and associating molecular liquids in relation to ultrasound absorption at atmospheric pressure, the same behavior in relation to ultrasound absorption can be supposed under high-pressures. ${ }^{7}$ Thus, because the ultrasound relaxation frequency decreases with increasing pressure in viscous associating molecular liquids, ${ }^{23}$ the same behavior should also be observed in ILs. As a consequence, the dispersion region should be shifted towards lower frequencies. Thus, trying to avoid the dispersion region during this work, the speed of sound in ultrapure $\left[\mathrm{C}_{6} \mathrm{C}_{1} \mathrm{im}\right]\left[\mathrm{NTf}_{2}\right]$ was measured at temperatures from $303 \mathrm{~K}$ to $323 \mathrm{~K}$ at pressures up to $101 \mathrm{MPa}$. For the same reason the speed of sound in $\left[\mathrm{C}_{5} \mathrm{C}_{1} \mathrm{im}\right]\left[\mathrm{NTf}_{2}\right]$ was measured at pressures up to $101 \mathrm{MPa}$ at temperatures from 
$298 \mathrm{~K}$ to $318 \mathrm{~K}$. To be able to further investigate the effect of the cation alkyl chain length on speed of sound in ILs, speeds of sound in $\left[\mathrm{C}_{3} \mathrm{C}_{1} \mathrm{im}\right]\left[\mathrm{NTf}_{2}\right]$ and $\left[\mathrm{C}_{4} \mathrm{C}_{1} \mathrm{im}\right]\left[\mathrm{NTf}_{2}\right]$ were also measured during this work at pressures up to $101 \mathrm{MPa}$ and for temperatures from $293 \mathrm{~K}$ to $318 \mathrm{~K}$ and from $293 \mathrm{~K}$ to $323 \mathrm{~K}$, respectively. The results of these measurements are listed in Table 2.

The speed of sound data, pressure and temperature were correlated by the equation:

$$
p-p_{0}=\sum_{i=1}^{3} \sum_{j=0}^{2} a_{i j}\left(u-u_{0}\right)^{i} T^{j},
$$

which was suggested by Sun et al. ${ }^{24}$

The $a_{i j}$ are parameters determined by a least-squares fit $u$ is the speed of sound at $p>0.1 \mathrm{MPa}, u_{0}$ is the speed of sound at atmospheric pressure $p_{0}=0.101325 \mathrm{MPa}$, reported in a previous paper. ${ }^{7}$ The coefficients $a_{i j}$ and the mean deviation of the experimental data from the correlation are given in Table 3. The stepwise rejection procedure was used to reduce the number of the non-zero coefficients. ${ }^{25}$ Speeds of sound in $\left[\mathrm{C}_{3} \mathrm{C}_{1} \mathrm{im}\right]\left[\mathrm{NTf}_{2}\right]$, $\left[\mathrm{C}_{4} \mathrm{C}_{1} \mathrm{im}\right]\left[\mathrm{NTf}_{2}\right]$ and $\left[\mathrm{C}_{5} \mathrm{C}_{1} \mathrm{im}\right]\left[\mathrm{NTf}_{2}\right]$ have been studied under high-pressure by three different laboratories, but all of the sample were synthesized and purified at the QUILL research Centre Belfast. Impurities such as lithium and halide contents were not reported by Esperança et al. ${ }^{9}$ and Gomes de Azevedo et al. ${ }^{10}$, while the water content of our $\left[\mathrm{C}_{3} \mathrm{C}_{1} \mathrm{im}\right]\left[\mathrm{NTf}_{2}\right]$ sample is lower (41 ppm) than of sample investigated by Esperança et al. ${ }^{9}$ ( $\left.<150 \mathrm{ppm}\right)$. However, the water content of our $\left[\mathrm{C}_{4} \mathrm{C}_{1} \mathrm{im}\right]\left[\mathrm{NTf}_{2}\right]$ sample $(171 \mathrm{ppm})$ is higher compared to that investigated by Gomes de Azevedo et al. ${ }^{10}$ (<75 ppm). In the case of [ $\left.\mathrm{C}_{5} \mathrm{C}_{1} \mathrm{im}\right]\left[\mathrm{NTf}_{2}\right]$, a water content lower than $150 \mathrm{ppm}$ was reported by Esperança et al. ${ }^{9}$ while $192 \mathrm{ppm}$ of water was detected in our sample during this work. It must be mentioned however, that previous investigations showed that differences in water content of about $80 \mathrm{ppm}$ did not affect the 
speed of sound. ${ }^{26,27}$ In case of $\left[\mathrm{C}_{3} \mathrm{C}_{1} \mathrm{im}\right]\left[\mathrm{NTf}_{2}\right]$ and $\left[\mathrm{C}_{5} \mathrm{C}_{1} \mathrm{im}\right]\left[\mathrm{NTf}_{2}\right]$, the differences between our data and the data of Esperança et al. ${ }^{9}$ increase systematically with pressure, while for $\left[\mathrm{C}_{4} \mathrm{C}_{1} \mathrm{im}\right]\left[\mathrm{NTf}_{2}\right]$ the differences between our data and the data of Gomes de Azevedo et al. ${ }^{10}$ are not regular (Figures 1-3). The maximum deviations between these data are $-11.8 \mathrm{~m} \cdot \mathrm{s}^{-1}$ and $-12.1 \mathrm{~m} \cdot \mathrm{s}^{-1}$ at $101 \mathrm{MPa}$ for $\left[\mathrm{C}_{3} \mathrm{C}_{1} \mathrm{im}\right]\left[\mathrm{NTf}_{2}\right]$ and $\left[\mathrm{C}_{5} \mathrm{C}_{1} \mathrm{im}\right]\left[\mathrm{NTf}_{2}\right]$, respectively. The observed deviations have the same magnitude at a given pressure independently on temperature and IL structure and are higher than the uncertainties of our data (i.e. $\left.1 \mathrm{~m} \cdot \mathrm{s}^{-1}\right)$ and those claimed by Esperança et al. ${ }^{9}$ (i.e. $0.05 \%$ ). These differences are probably due to the use the reference liquids for the calibration and the method of calibration applied by each group. In the case of $\left[\mathrm{C}_{4} \mathrm{C}_{1} \mathrm{im}\right]\left[\mathrm{NTf}_{2}\right]$, the differences are lower than the uncertainty claimed by Gomes de Azevedo et al. ${ }^{10}$ (i.e. $\pm 0.2 \%$ ), but are higher than those reported in this work (i.e. $1 \mathrm{~m} \cdot \mathrm{s}^{-1}$ ), as the maximum deviation observed between these two data sets is $-2.4 \mathrm{~m} \cdot \mathrm{s}^{-1}$ at $45.59 \mathrm{MPa}$ and 303.15 K. In Table 4, the Absolute Average Relative Deviations (AARD), Percent Relative Deviations (PRD), and Average Relative Deviations (BIAS) are summarized.

The calibration method used by Esperança et al., ${ }^{9}$ is based on a speed of sound datum for benzene that was reported by Sun et al. ${ }^{28}$ Additionally, Esperança et al. ${ }^{9}$ made further measurements with benzene, toluene, and methanol to analyze the accuracy of their calibration and compared the measured speeds of sound with results reported by Sun's group. They estimated "an uncertainty of $0.05 \%$ based on the standard deviations obtained for the

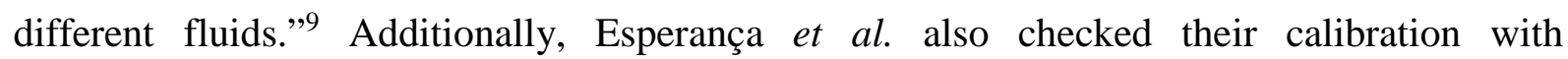
measurements in acetone. In this work, we decided to examine the internal coherence of speeds of sound in benzene under high-pressure as reported in literature $28-33$ and measured in this work (Table S1 of the Supporting Information) by adopting two polynomial equations: one proposed by Sun et al. ${ }^{23}$ (eq.1) and the other suggested by Esperança et al. ${ }^{9}$ (fitting parameters are reported in Tables S2, S3 and S4 of the Supporting Information). In order to 
enlarge the probability to find a global minimum of the last-squares fits, repeated calculations with a set of random starting values for the parameters have been performed. As the results for the parameters depend on the initial values, the global minimum can be found with high confidence. If most results coincide, it is very likely that the found minimum is the global minimum. Residuals increase systematically with increasing pressure for the data reported by Sun et $a .^{28}$ independent of the fitted polynomial equation (see Figures S1 and S2 in the Supporting Information). This is probably the main reasons for the increasing differences between our speeds of sound and the data of Esperança et al. ${ }^{9}$ at high-pressures.

The high-pressure acoustic and thermodynamic raw data sets for the IL family [C $\left.\mathrm{C}_{1} \mathrm{im}\right]\left[\mathrm{NTf}_{2}\right]$ ( $n=2$ to 6 ) are currently the most comprehensive data sets for ionic liquids in the literature. This allows us to study the irregular dependence of the speed of sound on alkyl chain length. For $\left[\mathrm{C}_{n} \mathrm{C}_{1} \mathrm{im}\right]\left[\mathrm{NTf}_{2}\right]$, a minimum of the speed of sound was noticed, but differences between the experimental data sets made it impossible to clearly establish the substance with the lowest speed of sound. This is related to the fact that very similar speed of sound data have been observed in $\left[\mathrm{C}_{4} \mathrm{C}_{1} \mathrm{im}\right]\left[\mathrm{NTf}_{2}\right]$, $\left[\mathrm{C}_{5} \mathrm{C}_{1} \mathrm{im}\right]\left[\mathrm{NTf}_{2}\right]$, and $\left[\mathrm{C}_{6} \mathrm{C}_{1} \mathrm{im}\right]\left[\mathrm{NTf}_{2}\right]$ under atmospheric pressure (see Figure 4). For $\left[\mathrm{C}_{2} \mathrm{C}_{1} \mathrm{im}\right]\left[\mathrm{NTf}_{2}\right]$ a very good agreement of the literature values is observed, the maximum difference between data sets ${ }^{34,35}$ of the speed of sound at $303.15 \mathrm{~K}$ is only $0.36 \mathrm{~m} \cdot \mathrm{s}^{-1}$. Additionally, this minimum of the speed of sound seems to shift with pressure towards the IL with a lower number of carbon atoms in the alkyl chain attached to the cation ring, such as for $\left[\mathrm{C}_{3} \mathrm{C}_{1} \mathrm{im}\right]\left[\mathrm{NTf}_{2}\right]$ at $100 \mathrm{MPa}$. The observation of a minimum of the speed of sound in the series of the $\left[\mathrm{C}_{n} \mathrm{C}_{1} \mathrm{im}\right]\left[\mathrm{NTf}_{2}\right]$ may be related to the dual nature of the interactions in these ILs which include, according to MD simulation studies, ${ }^{36-38}$ nonpolar-dispersive and ionic domains. Briefly, MD simulations have shown that 1-alkyl-3methylimidazolium ILs with side chains above butyl may have continuous polar and nonpolar domains, leading to a microstructure environment driven by the IL alkyl chains. The 
observed trends in the speed of sound for the $\left[\mathrm{C}_{n} \mathrm{C}_{1} \mathrm{im}\right]\left[\mathrm{NTf}_{2}\right]$ series may confirm the transition between globular and bicontinuous, sponge-like nanostructures. However, this mesoscopic effect has been also reported for several 1-alkyl-3-methylimidazolium-based ILs, ${ }^{37,39}$ which did not exhibit such a speed of sound behavior, i.e. that the speed of sound decreases with increasing number of carbon atoms. It may suggest that this nanostructure is anion dependent. In this context, the observed minimum value for the speed of sound in the case of the $\left[\mathrm{C}_{n} \mathrm{C}_{1} \mathrm{im}\right]\left[\mathrm{NTf}_{2}\right]$ series (see Figure 4 ) might be related to the structure of the $\left[\mathrm{NTf}_{2}\right]^{-}$anion, as the charge on its surface is more delocalized than other anions like $\left[\mathrm{BF}_{4}\right]^{-}$, $\left[\mathrm{PF}_{6}\right]^{-},[\mathrm{Br}]^{-}$or $[\mathrm{OH}]^{-}$, which results in relatively weaker cation-anion Coulombic interactions, thus reducing the likelihood of ion association in solution. With the alkyl chains length on $\left[\mathrm{C}_{n} \mathrm{C}_{1} \mathrm{im}\right]\left[\mathrm{NTf}_{2}\right]$ also the van der Waals forces increase, which may enhance the cohesive energy of the IL. ${ }^{44}$ This behavior may also be related to the increasing cohesive energy with pressure and to the fact that the minimum of the speed of sound could be shifted towards an IL with a lower number of carbon atoms in the alkyl chain length in $\left[\mathrm{C}_{n} \mathrm{C}_{1} \mathrm{im}\right]\left[\mathrm{NTf}_{2}\right]$.

\section{High-pressure density, isentropic compressibility and isobaric heat capacity.}

Using the experimental speeds of sound at high-pressures, determined in this work, together with the densities and isobaric heat capacities at atmospheric pressure, $p-\rho-T$ and $p-C_{p}-T$ data were calculated. Comparing them with literature data for high-pressure densities, isentropic compressibilities and isobaric heat capacities further evaluates the reliability of our results for the speed of sound. The pressure derivatives of the density and isobaric heat capacity were calculated using the following thermodynamic relationships:

$$
\left(\frac{\partial \rho}{\partial p}\right)_{T}=\frac{1}{u^{2}}+\frac{T \alpha_{p}^{2}}{C_{p}},
$$




$$
\left(\frac{\partial C_{p}}{\partial p}\right)_{T}=-\frac{T}{\rho}\left[\alpha_{p}^{2}+\left(\frac{\partial \alpha_{p}}{\partial T}\right)_{p}\right]
$$

where $\alpha_{p}$ is the isobaric thermal expansion coefficient which is calculated from definition $\alpha_{p}=-(1 / \rho)(\partial \rho / \partial T)_{p}$. The change of liquid density, $\Delta \rho$, caused by the change of pressure from $p_{1}$ to $p_{2}$ at constant temperature $T$ is obtained by integration of eqs. (2) and (3) over the entire pressure range covered by the speed of sound measurements and by using suitable initial conditions in the form of $\rho\left(T, p_{0}\right)$ and $C_{p}\left(T, p_{0}\right)$ functions at the initial pressure $p_{0}$, where $p_{0}$ is chosen as the atmospheric pressure:

$$
\Delta \rho=\int_{p_{1}}^{p_{2}}\left(\frac{1}{u^{2}}+\frac{\alpha^{2} T}{C_{p}}\right) d p \approx \int_{p_{1}}^{p_{2}} \frac{1}{u^{2}} d p+\frac{\alpha^{2} T}{C_{p}} \Delta p,
$$

where $\Delta p=p_{2}-p_{1}$. Thus, to calculate the density at $p_{2}$, values of $\rho, \alpha$ and $C_{p}$ at $p_{1}$ are necessary beside the speed of sound as a function of pressure. The approximate relationship (4) is sufficiently accurate, provided $\Delta p$ is small, because the heat capacity depends rather slightly on pressure. Moreover, the first term of the right hand side of eq. 4 is significantly larger than the second one, since the latter results from the difference between the isentropic and isothermal compressibilities that is rather small. The heat capacity at $p_{2}$ is given by:

$$
C_{p}\left(p_{2}\right) \approx C_{p}\left(p_{1}\right)-(T / \rho)\left\{\alpha^{2}+(\partial \alpha / \partial T)_{p}\right\} \Delta p
$$

where $C_{p}\left(p_{1}\right)$ is the isobaric heat capacity at $p_{1}$.

The expanded uncertainties ( $k=2$, level of confidence of 0.95 ) have been estimated to be better than $U(\rho)=5 \cdot 10^{-4} \rho \mathrm{kg} \cdot \mathrm{m}^{-3}$ and $U\left(C_{p}\right)=1 \cdot 10^{-2} C_{p} \mathrm{~J} \cdot \mathrm{mol}^{-1} \cdot \mathrm{K}^{-1}$ for the calculated density and isobaric molar heat capacity, respectively. The temperature dependence of the density at ambient pressure is presented in table 5. Speeds of sound and isobaric heat capacities under 
atmospheric pressure were taken from our previous works., ${ }^{7,45}$ Calculated densities and isobaric heat capacities at high-pressure are reported in Tables 5 and 6, respectively. With the calculated densities and experimental speed of sound data, the isentropic compressibilities were calculated by the Newton-Laplace equation $\kappa_{S}=\left(\rho u^{2}\right)^{-1}$. The expanded uncertainty ( $k=2$, level of confidence of 0.95$)$ of $\kappa_{S}$ is estimated to be $U\left(\kappa_{S}\right)=1.5 \cdot 10^{-3} \kappa_{S} \mathrm{TPa}^{-1}$. The results for the isentropic compressibility are given in Table 7 . As reported in Table 4, the calculated densities for $\left[\mathrm{C}_{3} \mathrm{C}_{1} \mathrm{im}\right]\left[\mathrm{NTf}_{2}\right],\left[\mathrm{C}_{4} \mathrm{C}_{1} \mathrm{im}\right]\left[\mathrm{NTf}_{2}\right]$, $\left[\mathrm{C}_{5} \mathrm{C}_{1} \mathrm{im}\right]\left[\mathrm{NTf}_{2}\right]$ and $\left[\mathrm{C}_{6} \mathrm{C}_{1} \mathrm{im}\right]\left[\mathrm{NTf}_{2}\right]$ at high-pressures are in a very good agreement with those obtained experimentally with high-pressure densimeters, ${ }^{9-13,46}$ while large deviations up to $-1.53 \%$ from the high-pressure specific volume data obtained using a dilatometer ${ }^{47}$ are observed. To illustrate our statistical analysis in Table 4, comparisons of thermophysical properties determined by the acoustic method as a function of pressure with those determined from high-pressure densitometer and dilatometer measurements as well as calculated data reported in literature are presented in Figures 5-7 and the maximum deviations are reported in the Supporting Information. As can be seen in Figures 5 and 7, the leading systematic error contribution to the calculated isentropic compressibility and isobaric heat capacity data arises mainly from the uncertainty of the speed of sound data, which becomes more significant at high-pressures. According to Table 4 and Figures 5 and 6, the largest deviations between our speed of sound data from those calculated using high-pressure experimental densities for $\left[\mathrm{C}_{6} \mathrm{C}_{1} \mathrm{im}\right]\left[\mathrm{NTf}_{2}\right]$ by Safarov et al. $^{13}$ and for $\left[\mathrm{C}_{4} \mathrm{C}_{1} \mathrm{im}\right]\left[\mathrm{NTf}_{2}\right]$ by Hamidova et al. ${ }^{12}$ are observed. For example, deviations up to $-45 \mathrm{~m} \cdot \mathrm{s}^{-1}$ at $99.55 \mathrm{MPa}$ and $313.15 \mathrm{~K}$ and up to -20 $\mathrm{m} \cdot \mathrm{s}^{-1}$ at $69.996 \mathrm{MPa}$ and $293.15 \mathrm{~K}$ are noticed for $\left[\mathrm{C}_{6} \mathrm{C}_{1} \mathrm{im}\right]\left[\mathrm{NTf}_{2}\right]$ and $\left[\mathrm{C}_{4} \mathrm{C}_{1} \mathrm{im}\right]\left[\mathrm{NTf}_{2}\right]$, respectively, indicating that this procedure is subject to enormous errors, and difficulties in assessing the influence of numerical methods on the calculated speeds of sound. 


\section{SUMMARY}

The speed of sound in four ultrapure ILs, namely $\left[\mathrm{C}_{3} \mathrm{C}_{1} \mathrm{im}\right]\left[\mathrm{NTf}_{2}\right],\left[\mathrm{C}_{4} \mathrm{C}_{1} \mathrm{im}\right]\left[\mathrm{NTf}_{2}\right]$, $\left[\mathrm{C}_{5} \mathrm{C}_{1} \mathrm{im}\right]\left[\mathrm{NTf}_{2}\right]$, and $\left[\mathrm{C}_{6} \mathrm{C}_{1} \mathrm{im}\right]\left[\mathrm{NTf}_{2}\right]$, has been measured as a function of the temperature and at pressures up to $101 \mathrm{MPa}$. During this work, special attention has been given to select the temperature range for each sample by taking into consideration their relaxation region. All speed of sound data have been compared with literature data by taking into account differences between the purities of each sample, experimental apparatuses used and their calibration, as well as, the selected procedure for fitting the data. Furthermore, the reliability of the speed of sound data has been evaluated by the calculation of the densities, isobaric heat capacities and isentropic compressibilities as the function of temperature and pressure using the acoustic method. Excluding data obtained using dilatometer, very good agreement between our results and those from the literature was observed confirming the reliability of the measured and calculated properties, which may be used to depict a structure-properties relationship for selected $\left[\mathrm{C}_{n} \mathrm{C}_{1} \mathrm{im}\right]\left[\mathrm{NTf}_{2}\right]$ series as a function of the alkyl chain length on the cation. Based on our experimental data and literature data, it appears that the speed of sound in the $\left[\mathrm{C}_{n} \mathrm{C}_{1} \mathrm{im}\right]\left[\mathrm{NTf}_{2}\right]$ series, with $n=2$ to 8 , reaches a minimum for $n$ between 4 and 6 at 0.1 $\mathrm{MPa}$, while this minimum seems to be shifted to a lower alkyl chain length with increasing pressure (e.g. $n=3$ as observed at $101 \mathrm{MPa}$ ). This finding may be related to the dual nature of the interactions in these ILs which include nonpolar-dispersive and ionic domains and may be used as a proof of the transition between globular and bicontinuous, sponge-like nanostructures transition observed by several research groups using MD simulations. Finally, it should be noted that measurements of ultrasound relaxation under high-pressures would be very useful to clarify the relaxation processes which occur in these ILs, especially for verifying the required conditions of their speed of sound data as a source for other thermodynamic properties. 


\section{Supporting Information.}

Speeds of sound in benzene are tabulated in Table S1. Fitting parameters for different correlations of the speed of sound in benzene are tabulated in Tables S2-S4. Residuals between experimental speeds of sound in benzene and calculated values from the correlations are shown in Figures S1-S2. High-pressure density, isentropic compressibility and molar isobaric heat capacity for $\left[\mathrm{C}_{3} \mathrm{C}_{1} \mathrm{im}\right]\left[\mathrm{NTf}_{2}\right], \quad\left[\mathrm{C}_{4} \mathrm{C}_{1} \mathrm{im}\right]\left[\mathrm{NTf}_{2}\right], \quad\left[\mathrm{C}_{5} \mathrm{C}_{1} \mathrm{im}\right]\left[\mathrm{NTf}_{2}\right]$, and $\left[\mathrm{C}_{6} \mathrm{C}_{1} \mathrm{im}\right]\left[\mathrm{NTf}_{2}\right]$ in comparison with the literature values.

This material is available free of charge via the Internet at http://pubs.acs.org.

\section{Corresponding Author}

* Marzena Dzida, University of Silesia, Institute of Chemistry, Szkolna 9, 40-006 Katowice, Poland, E-mail: mhd@ich.us.edu.pl

\section{Acknowledgement}

The work was financed by a statutory activity subsidy from the Polish Ministry of Science and Higher Education for the Institute of Chemistry of University of Silesia.

PG and JJ acknowledge gratefully the CEA le Ripault for supporting this work (Grant No 4600261677/P6E31).

\section{REFERENCES}

(1) Riazi, M. R.; Mansoori, G. A. Use of the Velocity of Sound in Predicting the PVT Relations. Fluid Phase Equilib.1993, 90, 251-264.

(2) Span, R.; Wagner, W. Equations of State for Technical Applications. I. Simultaneously Optimized Functional Forms for Nonpolar and Polar Fluids. Int. J. Thermophys. 2003, 24, 1-39.

(3) Lemmon, E. W.; Span, R. Short Fundamental Equations of State for 20 Industrial Fluids. J. Chem. Eng. Data 2006, 51, 785-850. 
(4) Bessières, D.; Plantier, F. Thermodynamic Consistency Between Calorimetric Acoustic and Volumetric Measurementents. J. Therm. Anal. Calorim. 2007, 89, 81-85.

(5) Żak, A.; Dzida, M.; Zorębski, M.; Ernst, S. A High Pressure Device for Measurements of the Speed of Sound in Liquids. Rev. Scient. Instr. 2000, 71, 1756-1768.

(6) Takagi, T.; Wilhelm, E. in Heat Capacities: Liquids, Solutions and Vapours; Wilhelm, E., Letcher, T. M., Eds.; RSC Publishing: Cambridge, 2010; pp 218-237.

(7) Zorębski, M.; Zorębski, E.; Dzida, M.; Skowronek, J.; Jężak, S.; Goodrich, P.; Jacquemin, J. Ultrasonic Relaxation Study of 1-Alkyl-3-methylimidazolium-Based RoomTemperature Ionic Liquids: Probing the Role of Alkyl Chain Length in the Cation. J. Phys. Chem. B 2016, 120, 3569-3581.

(8) Dzida, M.; Chorążewski, M.; Geppert-Rybczyńska, M.; Zorębski, E.; Zorębski, M.; Żarska, M.; Czech, B. Speed of Sound and Adiabatic Compressibility of 1-Ethyl-3methylimidazolium Bis(trifluoromethylsulfonyl)imide under Pressures up to $100 \mathrm{MPa}$. J. Chem. Eng. Data 2013, 58, 1571-1576.

(9) $\quad$ Esperança, J. M. S. S.; Visak, Z. P.; Plechkova, N.V.; Seddon, K. R.; Guedes, H. J. R.; Rebelo, L. P. N. Density, Speed of Sound, and Derived Thermodynamic Properties of Ionic Liquids over an Extended Pressure Range. 4. [ $\left.\mathrm{C}_{3} \mathrm{mim}\right]\left[\mathrm{NTf}_{2}\right]$ and $\left[\mathrm{C}_{5} \mathrm{mim}\right]\left[\mathrm{NTf}_{2}\right]$. J. Chem. Eng. Data 2006, 51, 2009-2015.

(10) Gomes de Azevedo, R.; Esperança, J. M. S. S.; Szydlowski, J.; Visak, Z. P.; Pires, P. F.; Guedes, H. J. R.; Rebelo, L. P. N. Thermophysical and Thermodynamic Properties of Ionic Liquids over an Extended Pressure Range: [bmim] $\left[\mathrm{NTf}_{2}\right]$ and [hmim] $\left[\mathrm{NTf}_{2}\right]$. J. Chem. Thermodyn. 2005, 37, 888-899.

(11) Gomes de Azevedo, R.; Esperança, J. M. S. S.; Najdanovic-Visak, V.; Visak, Z. P.; Guedes, H. J. R.; Nunes da Ponte, M.; Rebelo, L. P. N. Thermophysical and Thermodynamic Properties of 1-Butyl-3-methylimidazolium Tetrafluoroborate and 1-Butyl-3methylimidazolium Hexafluorophosphate over an Extended Pressure Range. J. Chem. Eng. Data 2005, 50, 997-1008.

(12) Hamidova, R.; Kul, I.; Safarov, J.; Shahverdiyev, A.; Hassel, E. Thermophysical Properties of 1-Butyl-3-methylimidazolium Bis(trifluoromethylsulfonyl)imide at High Temperatures and Pressures. Braz. J. Chem. Eng. 2015, 32, 303-316.

(13) Safarov, J.; Hamidova, R.; Zepik, S.; Schmidt, H.; Kul, I.; Shahverdiyev, A.; Hassel, E. Thermophysical Properties of 1-Hexyl-3-methylimidazolium Bis(trifluoro methylsulfonyl)imide at High Temperatures and Pressures. J. Mol. Liq. 2013, 187, 137-156. 
(14) Safarov, J.; Geppert-Rybczyńska, M; Kul, I.; Hassel, E. Thermophysical Properties of 1-Butyl-3-methylimidazolium Acetate Over a Wide Range of Temperatures and Pressures. Fluid Phase Equilib. 2014, 383, 144-155.

(15) Maghari, A.; ZiaMajidi, F.; Pashaei, E. Thermophysical Properties of Alkylimidazolium Based Ionic Liquids Through the Heterosegmented SAFT-BACK Equation of State. J. Mol. Liq. 2014, 191, 59-67.

(16) Maghari, A.; ZiaMajidi, F. Prediction of Thermodynamic Properties of Pure Ionic Liquids Through Extended SAFT-BACK Equation of State. Fluid Phase Equilib. 2013, 356, 109-116.

(17) Polishuk, I. Implementation of Perturbed-Chain Statistical Associating Fluid Theory (PC-SAFT), Generalized (G)SAFT+Cubic, and Cubic-Plus-Association (CPA) for Modeling Thermophysical Properties of Selected 1-Alkyl-3-methylimidazolium Ionic Liquids in a Wide Pressure Range. J. Phys. Chem. A 2013, 117, 2223-2232.

(18) Marsh, K. N.; Brennecke, J. F.; Chirico, R. D.; Frenkel, M.; Heintz, A.; Magee, J. W.; Peters, C. J.; Rebelo, L. P. N.; Seddon, K. R. Thermodynamic and Thermophysical Properties of the Reference Ionic Liquid: 1-Hexyl-3-methylimidazolium bis[(trifluoromethyl)sulfonyl]amide (including mixtures). Part 1. Experimental Methods and Results (IUPAC Technical Report). Pure Appl. Chem. 2009, 81, 781-790.

(19) Chirico, R. D.; Diky, V.; Magee, J. W.; Frenkel, M.; Marsh, K. N. Thermodynamic and Thermophysical Properties of the Reference Ionic Liquid: 1-Hexyl-3-methylimidazolium bis[(trifluoromethyl)sulfonyl]amide (including mixtures). Part 2. Critical Evaluation and Recommended Property Values (IUPAC Technical Report). Pure Appl. Chem. 2009, 81, 791828.

(20) Dzida, M.; Chorążewski, M.; Zorębski, M.; Mańka, R. Modifications of a High Pressure Device for Speed of Sound Measurements in Liquids. J. Phys. IV 2006, 137, 203207.

(21) Wagner, W.; Pruss, A. The IAPWS Formulation 1995 for the Thermodynamic Properties of Ordinary Water Substance for General and Scientific Use. J. Phys. Chem. Ref. Data 2002, 31, 387-535.

(22) Zorębski, E.; Geppert-Rybczyńska, M.; Zorębski, M. Acoustics as a Tool for Better Characterization of Ionic Liquids: A Comparative Study of 1-Alkyl-3-methylimidazolium Bis[(trifluoromethyl)sulfonyl]imide Room-Temperature Ionic Liquids. J. Phys. Chem. B 2013, 117, 3867-3876. 
(23) Herzfeld, K. F.; Litovitz, T. A. Absorption and Dispersion of Ultrasonic Waves; Academic Press: New York, 1959.

(24) Sun, T. F.; Biswas, S. N.; Trappeniers, N. J.; Ten Seldam, C. A. Acoustic and Thermodynamic Properties of Methanol from 273 to $333 \mathrm{~K}$ and at Pressures to $280 \mathrm{MPa}$. J. Chem. Eng. Data 1988, 33, 395-398.

(25) Czerminski J.; Iwasiewicz A.; Paszek Z.; Sikorski A. Statistical Methods in Applied Chemistry; Elsevier, 1990.

(26) Widegren, J. A.; Magee, J. W. Density, Viscosity, Speed of Sound, and Electrolytic Conductivity for the Ionic Liquid 1-Hexyl-3-methylimidazolium Bis(trifluoromethylsulfonyl) imide and Its Mixtures with Water. J. Chem. Eng. Data 2007, 52, 2331-2338.

(27) Skowronek, J.; Geppert-Rybczyńska, M.; Jacquemin, J.; Goodrich, P.; Alvarez, J. V.; Chorążewski, M.; Jężak, S.; Zorębski, E.; Zorębski, M.; Żarska, M.; Kaca, W.; Berdyczko, P.; Dzida, M. Acoustic and Volumetric Properties of Diluted Solutions of Water in Ionic Liquids. J. Sol. Chem. 2015, 44, 824-883.

(28) Sun, T. F.; Kortbeek, P. J.; Trappeniers, N. J.; Biswas, S. N. Acoustic and Thermodynamic Properties of Benzene and Cyclohexane as a Function of Pressure and Temperature. Phys. Chem. Liq. 1987, 16, 163-178.

(29) Bobik, M. Thermodynamic Quantities for Liquid Benzene 1. Sound Velocities Between 283 and $463 \mathrm{~K}$ and up to $62 \mathrm{MPa}$. J. Chem. Thermodyn. 1978, 10, 1137-1146.

(30) Goodwin, R. D. Benzene Thermophysical Properties from 279 to $900 \mathrm{~K}$ at Pressures to 1000 Bar. J. Phys. Chem. Ref. Data 1988, 17, 1541-1636.

(31) Zotov, V. V.; Melikhov, Y. F.; Melnikov, G. A.; Neruchev, Y. A. Sound Velocity in Liquid Hydrocarbons; Kursk State Pedagogical University Publ.: Kursk, 1995 (in Russian). (32) Takagi, T.; Sawada, K.; Urakawa, H.; Ueda, M.; Cibulka, I. Speed of Sound in Liquid Tetrachloromethane and Benzene at Temperatures from 283.15 K to 333.15 K and Pressures up to 30 MPa. J. Chem. Thermodyn. 2004, 36, 659-664.

(33) Wegge, R.; Richter, M.; Span, R. Speed of Sound Measurements in Ethanol and Benzene over the Temperature Range from (253.2 to 353.2) K at Pressures up to $30 \mathrm{MPa} . J$. Chem. Eng. Data 2015, 60, 1345-1353.

(34) Seoane, R. G.; Corderí, S.; Gomez, E.; Calvar, N.; Gonzalez, E. J.; Macedo, E. A.; Domínguez, A. Temperature Dependence and Structural Influence on the Thermophysical Properties of Eleven Commercial Ionic Liquids. Ind. Eng. Chem. Res. 2012, 51, 2492-2504.

(35) Bansal, S.; Kaur, N.; Chaudhary, G. R.; Mehta, S. K.; Ahluwalia, A. S. Physiochemical Properties of New Formulations of 1-Ethyl-3-methylimidazolium 
Bis(trifluoromethylsulfonyl)imide with Tritons. J. Chem. Eng. Data 2014, 59, 3988-3999.

(36) Canongia Lopes, J. N.; Costa Gomes, M. F.; Pádua, A. A. H. Nonpolar, Polar, and Associating Solutes in Ionic Liquids. J. Phys. Chem. B 2006, 110, 16816-16818.

(37) Canongia Lopes, J. N.; Pádua, A. A. H. Nanostructural Organization in Ionic Liquids. J. Phys. Chem. B 2006, 110, 3330-3335.

(38) Gutel, T.; Santini, C. C.; Philippot, K.; Padua, A.; Pelzer, K.; Chaudret, B.; Chauvin, Y.; Basset, J.-M. Organized 3D-Alkyl Imidazolium Ionic Liquids Could Be Used to Control the Size of in situ Generated Ruthenium Nanoparticles? J. Mater. Chem. 2009, 19, 3624 3631.

(39) Hayes, R.; Warr, G. G.; Atkin, R. Structure and Nanostructure in Ionic Liquids. Chem. Rev. 2015, 115, 6357-6426.

(40) Gómez, E.; Calvar, N.; Macedo, E. A.; Domínguez, A. Effect of the Temperature on the Physical Properties of Pure 1-Propyl-3-methylimidazoliumBis(trifluoromethyl sulfonyl)imide and Characterization of its Binary Mixtures with Alcohols. J. Chem. Thermodyn. 2012, 45, 9-15.

(41) Makino, W.; Kishikawa, R.; Mizoshiri, M.; Takeda, S.; Yao, M. Viscoelastic Properties of Room Temperature Ionic Liquids. J. Chem. Phys. 2008, 129, 104510. (42) Geppert-Rybczyńska, M.; Sitarek, M. Acoustic and Volumetric Properties of Binary Mixtures of Ionic Liquid 1-Butyl-3-methylimidazolium Bis(trifluoromethylsulfonyl)imide with Acetonitrile and Tetrahydrofuran. J. Chem. Eng. Data 2014, 59, 1213-1224.

(43) Gonzales, E. J.; Domínguez, A.; Macedo, E. A. Excess Properties of Binary Mixtures Containing 1-Hexyl-3-methylimidazolium bis(trifluoromethylsulfonyl)imide Ionic Liquid and Polar Organic Compounds. J. Chem. Thermodyn. 2012, 47, 300-311.

(44) Jacquemin, J.; Husson, P.; Pádua. A. A. H.; Majer, V. Density and Viscosity of Several Pure and Water-Saturated Ionic Liquids. Green Chem. 2006, 8, 172-180.

(45) Zorębski, E.; Zorębski, M.; Dzida, M.; Skowronek, J.; Goodrich, P.; Jacquemin, J. Heat Capacities of Imidazolium-Based and Pyrrolidinium-Based Ionic Liquids as a Function of Temperature: Experimental and Modeling. Ind. Eng. Chem. Res. 2016 (under preparation). (46) Currás, M. R.; Husson, P.; Pádua, A. A. H.; Costa Gomes, M. F.; García, J. HighPressure Densities of 2,2,2-Trifluoroethanol + Ionic Liquid Mixtures Useful for Possible Applications in Absorption Cycles. Ind. Eng. Chem. Res. 2014, 53, 10791-10802.

(47) Wojnarowska, Z.; Jarosz, G.; Grzybowski, A.; Pionteck, J.; Jacquemin, J.; Paluch, M. On the Scaling Behavior of Electric Conductivity in [ $\left.\mathrm{C}_{4} \mathrm{mim}\right]\left[\mathrm{NTf}_{2}\right]$. Phys. Chem. Chem. Phys. 2014, 16, 20444-20450. 
Table 1. Specification of Chemicals

\begin{tabular}{|c|c|c|c|c|c|c|}
\hline $\begin{array}{l}\text { Chemical's } \\
\text { acronym }\end{array}$ & CAS number & $\begin{array}{c}M \\
\text { o.mol }-1\end{array}$ & mass fraction & $\begin{array}{l}\text { Water } \\
\text { content }\end{array}$ & $\begin{array}{c}\mathrm{Br} \\
\text { content }\end{array}$ & $\begin{array}{c}\mathrm{Li} \\
\text { content }\end{array}$ \\
\hline & & & & $\mathrm{ppm}^{a}$ & $\mathrm{ppm}^{b}$ & $\mathrm{ppm}^{c}$ \\
\hline$\left[\mathrm{C}_{3} \mathrm{C}_{1} \mathrm{im}\right]\left[\mathrm{NTf}_{2}\right]$ & 216299-72-8 & 405.34 & $>99.95$ & 41 & $<5$ & 26 \\
\hline$\left[\mathrm{C}_{4} \mathrm{C}_{1} \mathrm{im}\right]\left[\mathrm{NTf}_{2}\right]$ & 174899-83-3 & 419.37 & $>99.95$ & 171 & $<5$ & 19 \\
\hline$\left[\mathrm{C}_{5} \mathrm{C}_{1} \mathrm{im}\right]\left[\mathrm{NTf}_{2}\right]$ & 280779-53-5 & 433.38 & $>99.95$ & 192 & $<5$ & 34 \\
\hline$\left[\mathrm{C}_{6} \mathrm{C}_{1} \mathrm{im}\right]\left[\mathrm{NTf}_{2}\right]$ & $382150-50-7$ & 447.42 & $>99.95$ & 101 & $<5$ & 23 \\
\hline
\end{tabular}

${ }^{a}$ Coulometric Karl Fisher titration, TitroLine 7500. ${ }^{b}$ AgNO3 titration. ${ }^{c}$ Inductively Coupled Plasma - Optical Emission Spectrometry (ICP-OES), Thermo Scientific iCAP 7200. 
Table 2. Experimental speeds of sound in $\left[\mathrm{C}_{3} \mathrm{C}_{1} \mathrm{im}\right]\left[\mathrm{NTf}_{2}\right], \quad\left[\mathrm{C}_{4} \mathrm{C}_{1} \mathrm{im}\right]\left[\mathrm{NTf}_{2}\right]$,

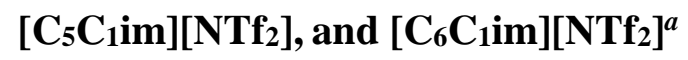

\begin{tabular}{|c|c|c|c|c|c|c|c|c|c|c|c|}
\hline$T / \mathrm{K}$ & $p / \mathrm{MPa}$ & $u / \mathrm{m}^{\prime} \mathrm{s}^{-1}$ & $T / \mathrm{K}$ & $p / \mathrm{MPa}$ & $u / \mathrm{m}^{\prime} \mathrm{s}^{-1}$ & $T / \mathrm{K}$ & $p / \mathrm{MPa}$ & $u / \mathrm{m}^{\prime} \mathrm{s}^{-1}$ & $T / \mathrm{K}$ & \multicolumn{2}{|c|}{$p / \mathrm{MPa} u / \mathrm{m} \cdot \mathrm{s}^{-1}$} \\
\hline \multicolumn{3}{|c|}{$\left[\mathrm{C}_{3} \mathrm{C}_{1} \mathrm{im}\right]\left[\mathrm{NTf}_{2}\right]$} & \multicolumn{3}{|c|}{$\left[\mathrm{C}_{4} \mathrm{C}_{1} \mathrm{im}\right]\left[\mathrm{NTf}_{2}\right]$} & \multicolumn{3}{|c|}{$\left[\mathrm{C}_{5} \mathrm{C}_{1} \mathrm{im}\right]\left[\mathrm{NTf}_{2}\right]$} & \multicolumn{3}{|c|}{$\left[\mathrm{C}_{6} \mathrm{C}_{1} \mathrm{im}\right]\left[\mathrm{NTf}_{2}\right]$} \\
\hline 292.90 & 15.20 & 1289.9 & 292.99 & 15.20 & 1287.0 & 298.21 & 15.20 & 1277.4 & 303.06 & 15.20 & 1267.6 \\
\hline 292.89 & 30.39 & 1333.8 & 292.99 & 30.39 & 1332.4 & 298.18 & 30.39 & 1324.3 & 303.05 & 30.39 & 1316.1 \\
\hline 292.89 & 45.59 & 1374.6 & 292.99 & 45.59 & 1374.4 & 298.17 & 45.59 & 1367.9 & 303.05 & 45.59 & 1360.8 \\
\hline 292.90 & 60.79 & 1413.0 & 292.99 & 60.79 & 1413.8 & 298.17 & 60.79 & 1408.4 & 303.05 & 60.79 & 1402.3 \\
\hline 292.90 & 75.99 & 1449.0 & 292.99 & 75.99 & 1450.7 & 298.17 & 75.99 & 1446.5 & 303.05 & 75.99 & 1441.4 \\
\hline 292.91 & 91.18 & 1483.2 & 292.99 & 91.18 & 1485.7 & 298.16 & 91.18 & 1482.5 & 303.05 & 91.19 & 1478.3 \\
\hline 292.91 & 101.32 & 1505.2 & 292.99 & 101.32 & 1508.1 & 298.16 & 101.32 & 1505.5 & 303.05 & 101.32 & 1501.8 \\
\hline 298.08 & 15.20 & 1278.1 & 298.16 & 15.20 & 1275.8 & 303.14 & 15.20 & 1266.9 & 308.06 & 15.20 & 1257.1 \\
\hline 298.07 & 30.39 & 1322.5 & 298.16 & 30.39 & 1321.5 & 303.14 & 30.39 & 1314.3 & 308.06 & 30.39 & 1306.0 \\
\hline 298.07 & 45.59 & 1363.8 & 298.16 & 45.59 & 1364.1 & 303.14 & 45.59 & 1358.0 & 308.05 & 45.59 & 1351.0 \\
\hline 298.07 & 60.79 & 1402.5 & 298.16 & 60.79 & 1403.7 & 303.14 & 60.79 & 1398.9 & 308.05 & 60.79 & 1393.1 \\
\hline 298.07 & 75.99 & 1439.0 & 298.16 & 75.99 & 1441.1 & 303.14 & 75.99 & 1437.3 & 308.05 & 75.99 & 1432.4 \\
\hline 298.06 & 91.18 & 1473.5 & 298.17 & 91.18 & 1476.3 & 303.14 & 91.18 & 1473.5 & 308.05 & 91.19 & 1469.5 \\
\hline 298.07 & 101.32 & 1495.2 & 298.17 & 101.32 & 1498.5 & 303.14 & 101.32 & 1496.7 & 308.05 & 101.32 & 1493.2 \\
\hline 303.14 & 15.20 & 1266.7 & 303.13 & 15.20 & 1265.3 & 308.11 & 15.20 & 1256.5 & 313.03 & 15.20 & 1246.9 \\
\hline 303.14 & 30.39 & 1311.8 & 303.14 & 30.39 & 1311.6 & 308.11 & 30.39 & 1304.2 & 313.03 & 30.39 & 1296.2 \\
\hline 303.14 & 45.59 & 1353.4 & 303.14 & 45.59 & 1354.2 & 308.10 & 45.59 & 1348.4 & 313.03 & 45.59 & 1341.6 \\
\hline 303.14 & 60.79 & 1392.6 & 303.14 & 60.79 & 1394.4 & 308.10 & 60.80 & 1389.7 & 313.03 & 60.79 & 1383.9 \\
\hline 303.13 & 75.99 & 1429.4 & 303.14 & 75.99 & 1431.9 & 308.10 & 75.99 & 1428.3 & 313.02 & 75.99 & 1423.5 \\
\hline 303.13 & 91.18 & 1464.1 & 303.14 & 91.18 & 1467.3 & 308.10 & 91.18 & 1464.8 & 313.02 & 91.19 & 1460.9 \\
\hline 303.14 & 101.32 & 1486.3 & 303.15 & 101.32 & 1490.1 & 308.10 & 101.32 & 1488.1 & 313.02 & 101.32 & 1484.7 \\
\hline 308.15 & 15.20 & 1256.3 & 308.12 & 15.20 & 1255.0 & 313.05 & 15.20 & 1246.2 & 318.00 & 15.20 & 1236.5 \\
\hline 308.14 & 30.39 & 1301.6 & 308.13 & 30.39 & 1301.6 & 313.04 & 30.39 & 1294.4 & 318.00 & 30.39 & 1286.4 \\
\hline 308.14 & 45.59 & 1343.8 & 308.13 & 45.59 & 1344.7 & 313.03 & 45.59 & 1339.0 & 318.00 & 45.59 & 1332.2 \\
\hline 308.13 & 60.80 & 1383.1 & 308.12 & 60.79 & 1385.0 & 313.02 & 60.80 & 1380.5 & 317.99 & 60.79 & 1375.0 \\
\hline 308.13 & 75.99 & 1420.2 & 308.14 & 75.99 & 1422.9 & 313.02 & 75.99 & 1419.5 & 317.99 & 75.99 & 1414.9 \\
\hline 308.14 & 91.18 & 1455.2 & 308.12 & 91.18 & 1458.7 & 313.03 & 91.18 & 1456.2 & 317.99 & 91.19 & 1452.5 \\
\hline 308.12 & 101.32 & 1477.6 & 308.14 & 101.32 & 1481.5 & 313.03 & 101.32 & 1479.7 & 317.99 & 101.32 & 1476.4 \\
\hline 313.11 & 15.20 & 1246.2 & 313.09 & 15.20 & 1245.0 & 318.34 & 15.20 & 1235.6 & 323.37 & 0.10 & 1169.6 \\
\hline
\end{tabular}




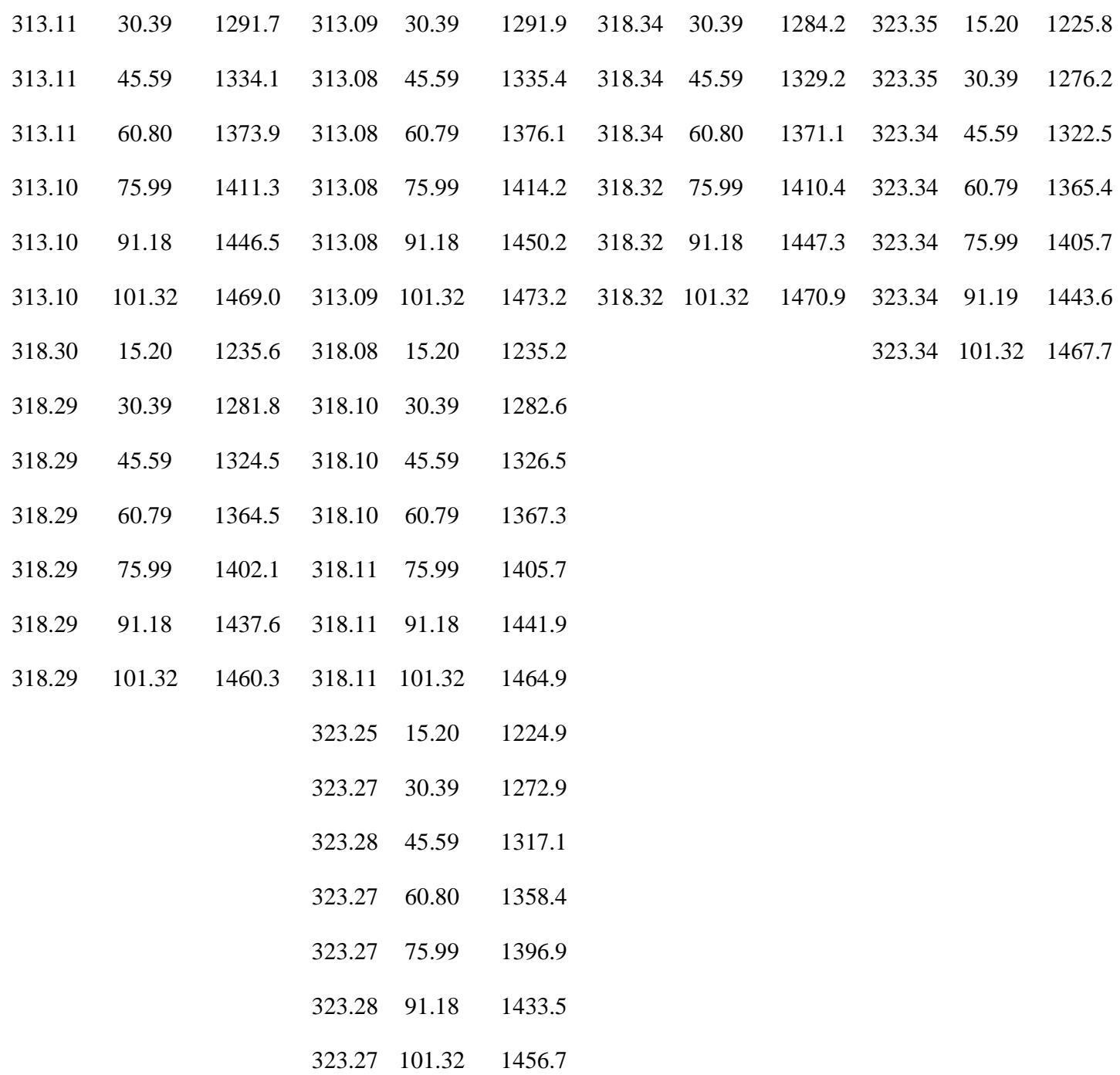

${ }^{a}$ The standard uncertainties $u$ at high pressures are $u_{p}=0.0015 \cdot p \mathrm{MPa}, u_{T}=0.05 \mathrm{~K}$, and the expanded uncertainty ( $k=2$, level of confidence of 0.95$), U$, is $U(u)=1 \mathrm{~m} \cdot \mathrm{s}^{-1}$ 
Table 3. Coefficients of equation (1) together with mean deviation ( $\delta u)$

\begin{tabular}{|c|c|c|c|c|c|}
\hline component & & $a_{1 j} / \mathrm{K}^{-j} \cdot \mathrm{MPa} \cdot \mathrm{s} \cdot \mathrm{m}^{-1}$ & $a_{2 j} / \mathrm{K}^{-j} \cdot \mathrm{MPa} \cdot \mathrm{s}^{2} \cdot \mathrm{m}^{-2}$ & $a_{3 j} / \mathrm{K}^{-j} \cdot \mathrm{MPa} \cdot \mathrm{s}^{3} \cdot \mathrm{m}^{-3}$ & $\delta u / \mathrm{m} \cdot \mathrm{s}^{-1}$ \\
\hline & $j$ & & & & \\
\hline \multirow[t]{3}{*}[\mathrm{C}_{3}\mathrm{C}_{1}\mathrm{im}]{$\left[\mathrm{NTf}_{2}\right]$} & 0 & $3.66428 \cdot 10^{-1}$ & $4.66959 \cdot 10^{-4}$ & - & 0.10 \\
\hline & 1 & - & - & - & \\
\hline & 2 & $-6.97455 \cdot 10^{-7}$ & $-2.36179 \cdot 10^{-9}$ & $1.51466 \cdot 10^{-12}$ & \\
\hline \multirow[t]{3}{*}[\mathrm{C}_{4}\mathrm{C}_{1}\mathrm{im}]{$\left[\mathrm{NTf}_{2}\right]$} & 0 & $3.85662 \cdot 10^{-1}$ & $3.41127 \cdot 10^{-4}$ & $3.64054 \cdot 10^{-8}$ & 0.07 \\
\hline & 1 & - & - & - & \\
\hline & 2 & $-1.09664 \cdot 10^{-6}$ & $-5.32239 \cdot 10^{-10}$ & - & \\
\hline \multirow[t]{3}{*}[\mathrm{C}_{5}\mathrm{C}_{1}\mathrm{im}]{$\left[\mathrm{NTf}_{2}\right]$} & 0 & $3.75240 \cdot 10^{-1}$ & $4.06025 \cdot 10^{-4}$ & $4.98655 \cdot 10^{-8}$ & 0.05 \\
\hline & 1 & - & $-4.22905 \cdot 10^{-7}$ & - & \\
\hline & 2 & $-1.06492 \cdot 10^{-6}$ & - & - & \\
\hline \multirow[t]{3}{*}[\mathrm{C}_{6}\mathrm{C}_{1}\mathrm{im}]{$\left[\mathrm{NTf}_{2}\right]$} & 0 & $4.96223 \cdot 10^{-1}$ & $2.91781 \cdot 10^{-4}$ & - & 0.09 \\
\hline & 1 & $-7.53305 \cdot 10^{-4}$ & - & - & \\
\hline & 2 & - & - & - & \\
\hline
\end{tabular}


Table 4. Comparison of speeds of sound, densities, and isentropic compressibilities obtained in this work with literature data

\begin{tabular}{|c|c|c|c|}
\hline IL & $\begin{array}{l}\text { Absolute Average } \\
\text { Relative Deviation } \\
\qquad A A R D \%^{a}\end{array}$ & $\begin{array}{c}\text { Percent Relative } \\
\text { Deviations } \\
\text { PRD } \%^{b}\end{array}$ & $\begin{array}{c}\text { Average Relative } \\
\text { Deviation } \\
\text { BIAS } \%^{c}\end{array}$ \\
\hline \multicolumn{4}{|c|}{ speed of sound } \\
\hline$\left[\mathrm{C}_{3} \mathrm{C}_{1} \mathrm{im}\right]\left[\mathrm{NTf}_{2}\right]^{d}$ & 0.65 & $-0.81 \div-0.35$ & -0.65 \\
\hline$\left[\mathrm{C}_{4} \mathrm{C}_{1} \mathrm{im}\right]\left[\mathrm{NTf}_{2}\right]^{e}$ & 0.08 & $-0.20 \div 0.12$ & -0.05 \\
\hline$\left[\mathrm{C}_{4} \mathrm{C}_{1} \mathrm{im}\right]\left[\mathrm{NTf}_{2}\right]^{f^{*}}$ & 0.90 & $-0.08 \div 1.40$ & 0.89 \\
\hline$\left[\mathrm{C}_{5} \mathrm{C}_{1} \mathrm{im}\right]\left[\mathrm{NTf}_{2}\right]^{d}$ & 0.61 & $-0.81 \div-0.31$ & -0.61 \\
\hline$\left[\mathrm{C}_{6} \mathrm{C}_{1} \mathrm{im}\right]\left[\mathrm{NTf}_{2}\right]^{g^{*}}$ & 1.57 & $-3.07 \div 2.23$ & -0.19 \\
\hline \multicolumn{4}{|c|}{ isentropic compressibility } \\
\hline$\left[\mathrm{C}_{3} \mathrm{C}_{1} \mathrm{im}\right]\left[\mathrm{NTf}_{2}\right]^{d}$ & 1.2 & $0.84 \div 1.5$ & 1.2 \\
\hline$\left[\mathrm{C}_{4} \mathrm{C}_{1} \mathrm{im}\right]\left[\mathrm{NTf}_{2}\right]^{e}$ & 0.16 & $-0.15 \div 0.32$ & 0.14 \\
\hline$\left[\mathrm{C}_{5} \mathrm{C}_{1} \mathrm{im}\right]\left[\mathrm{NTf}_{2}\right]^{d}$ & 1.1 & $0.85 \div 1.5$ & 1.1 \\
\hline \multicolumn{4}{|c|}{ isobaric heat capacity } \\
\hline$\left[\mathrm{C}_{4} \mathrm{C}_{1} \mathrm{im}\right]\left[\mathrm{NTf}_{2}\right]^{e}$ & 5.8 & $3.4 \div 7.8$ & 5.8 \\
\hline$\left[\mathrm{C}_{4} \mathrm{C}_{1} \mathrm{im}\right]\left[\mathrm{NTf}_{2}\right]^{f^{*}}$ & 0.17 & $-0.46 \div 0.09$ & -0.14 \\
\hline$\left[\mathrm{C}_{6} \mathrm{C}_{1} \mathrm{im}\right]\left[\mathrm{NTf}_{2}\right]^{g^{*}}$ & 3.2 & $-3.7 \div-2.6$ & -3.2 \\
\hline
\end{tabular}

density

\begin{tabular}{lcccccc}
\hline & Exp. & Acoust. & Exp. & Acoust. & Exp. & Acoust. \\
{$\left[\mathrm{C}_{3} \mathrm{C}_{1} \mathrm{im}\right]\left[\mathrm{NTf}_{2}\right]^{d}$} & 0.08 & 0.09 & $-0.12 \div-0.003$ & $-0.004 \div 0.24$ & -0.07 & -0.003 \\
{$\left[\mathrm{C}_{4} \mathrm{C}_{1} \mathrm{im}\right]\left[\mathrm{NTf}_{2}\right]^{e}$} & 0.03 & 0.05 & $-0.08 \div 0.10$ & $-0.09 \div 0.05$ & -0.02 & -0.05 \\
{$\left[\mathrm{C}_{4} \mathrm{C}_{1} \mathrm{im}\right]\left[\mathrm{NTf}_{2}\right]^{f}$} & 0.06 & - & $-0.08 \div-0.03$ & - & -0.06 & - \\
{$\left[\mathrm{C}_{4} \mathrm{C}_{1} \mathrm{im}\right]\left[\mathrm{NTf}_{2}\right]^{h}$} & 0.05 & - & $0.03 \div 0.08$ & - & 0.05 & - \\
{$\left[\mathrm{C}_{4} \mathrm{C}_{1} \mathrm{im}\right]\left[\mathrm{NTf}_{2}\right]^{i}$} & $1.03^{j}$ & - & $-1.53 \div-0.05$ & - & -1.03 & -
\end{tabular}




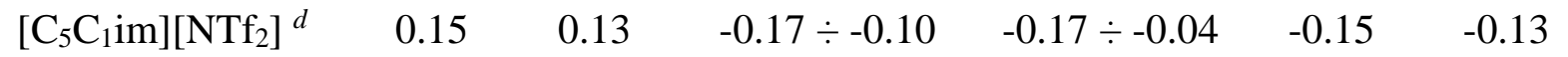

$\left[\mathrm{C}_{6} \mathrm{C}_{1} \mathrm{im}\right]\left[\mathrm{NTf}_{2}\right]^{e} \quad 0.09 \quad-\quad-0.06 \div 0.16 \quad-0.09 \quad-$

$\left[\mathrm{C}_{6} \mathrm{C}_{1} \mathrm{im}\right]\left[\mathrm{NTf}_{2}\right]^{g} \quad 0.052 \quad-\quad-0.07 \div 0.03 \quad-\quad-0.047 \quad-$

${ }^{a} \mathrm{AARD}=(100 / N) \sum_{i=1}^{n}\left|\left(y_{1, i}-y_{2, i}\right) / y_{1, i}\right|, \quad{ }^{b} \operatorname{PRD}=100\left(y_{1, i}-y_{2, i}\right) / y_{1, i}, \quad{ }^{c} \operatorname{BIAS}=(100 / N) \sum_{i=1}^{n}\left(y_{1, i}-y_{2, i}\right) / y_{1, i}$, where $N$ is the number of points of the data set considered. $y_{1}$ - data reported in this work, $y_{2}$ - data reported by ${ }^{d}$ Esperança et al. ${ }^{9},{ }^{e}$ Gomes de Azevedo et al. ${ }^{10},{ }^{f}$ Hamidova et $a l .{ }^{12},{ }^{g}$ Safarov et $a l .{ }^{13},{ }^{h}$ Currás et $a l .{ }^{46}$, or ${ }^{i}$ Wojnarowska et al. ${ }^{47}$, Exp. - measured by means of vibrating tube densimeter or ${ }^{j}$ dilatometer; Acoust. calculated by the acoustic method, * - calculated from $p$ - $\rho$ - $T$ data 
Table 5. Densities of $\left[\mathrm{C}_{3} \mathrm{C}_{1} \mathrm{im}\right]\left[\mathrm{NTf}_{2}\right], \quad\left[\mathrm{C}_{4} \mathrm{C}_{1} \mathrm{im}\right]\left[\mathrm{NTf}_{2}\right], \quad\left[\mathrm{C}_{5} \mathrm{C}_{1} \mathrm{im}\right]\left[\mathrm{NTf}_{2}\right]$, and [C6C1im][NTf 2 ]

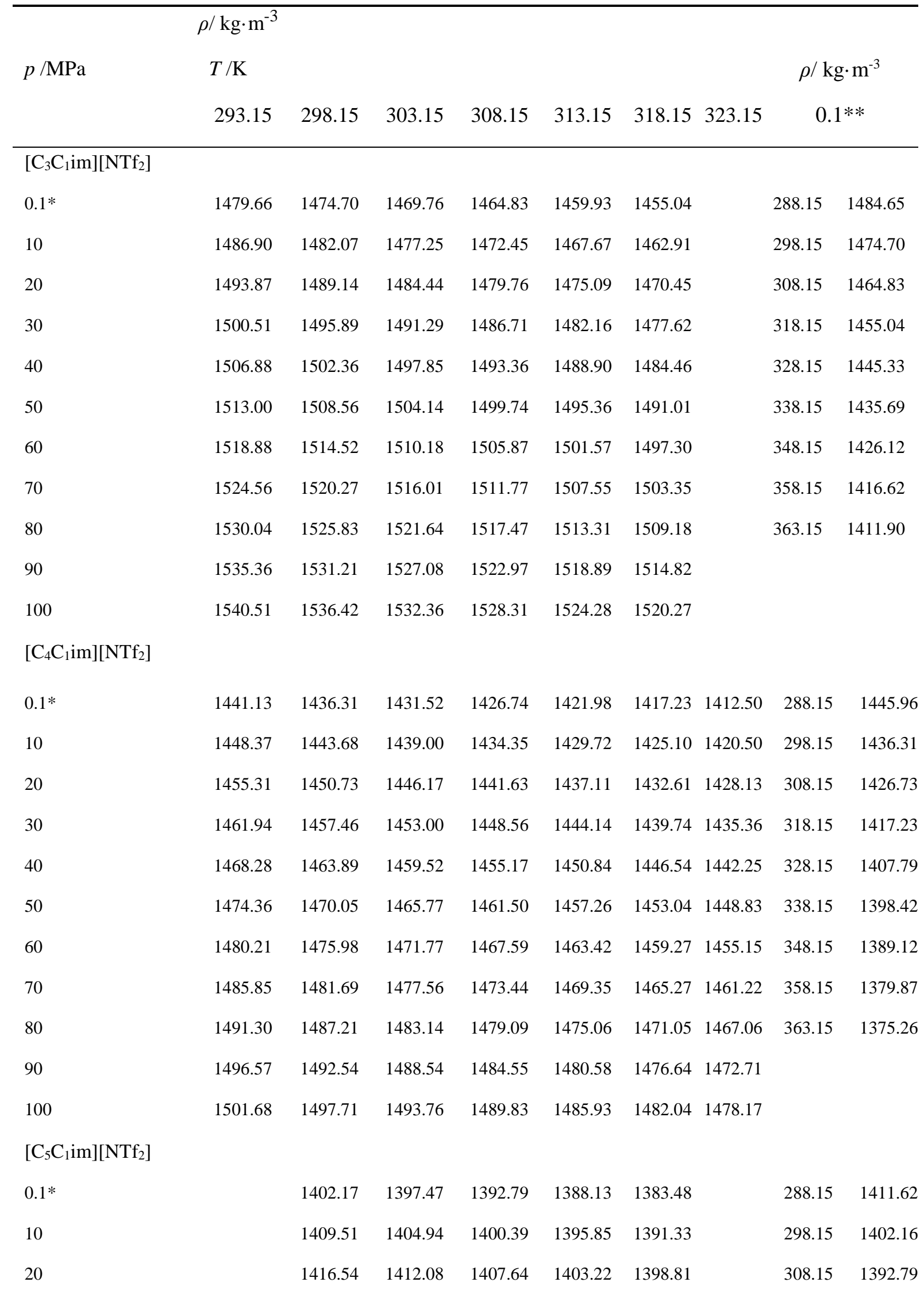




\begin{tabular}{|c|c|c|c|c|c|c|c|c|}
\hline 30 & 1423.22 & 1418.87 & 1414.53 & 1410.21 & \multicolumn{2}{|l|}{1405.91} & 318.15 & 1383.47 \\
\hline 40 & 1429.61 & 1425.34 & 1421.10 & 1416.87 & \multicolumn{2}{|l|}{1412.67} & 328.15 & 1374.23 \\
\hline 50 & 1435.73 & 1431.55 & 1427.38 & 1423.24 & \multicolumn{2}{|l|}{1419.12} & 338.15 & 1365.05 \\
\hline 60 & 1441.60 & 1437.50 & 1433.42 & 1429.35 & \multicolumn{2}{|l|}{1425.31} & 348.15 & 1355.92 \\
\hline 70 & 1447.26 & 1443.23 & 1439.22 & 1435.23 & \multicolumn{2}{|l|}{1431.25} & 358.15 & 1346.85 \\
\hline 80 & 1452.72 & 1448.76 & 1444.81 & 1440.89 & \multicolumn{2}{|l|}{1436.98} & 363.15 & 1342.34 \\
\hline 90 & 1458.00 & 1454.10 & 1450.22 & 1446.35 & \multicolumn{4}{|l|}{1442.51} \\
\hline 100 & 1463.11 & 1459.27 & 1455.45 & 1451.64 & \multicolumn{4}{|l|}{1447.85} \\
\hline \multicolumn{9}{|c|}{$\left[\mathrm{C}_{6} \mathrm{C}_{1} \mathrm{im}\right]\left[\mathrm{NTf}_{2}\right]$} \\
\hline $0.1^{*}$ & & 1367.08 & 1362.49 & 1357.91 & 1353.35 & 1348.81 & 288.15 & 1380.95 \\
\hline 10 & & 1374.53 & 1370.07 & 1365.63 & 1361.20 & 1356.78 & 298.15 & 1371.68 \\
\hline 20 & & 1381.66 & 1377.31 & 1372.97 & 1368.66 & 1364.36 & 308.15 & 1362.48 \\
\hline 30 & & 1388.42 & 1384.17 & 1379.94 & 1375.73 & 1371.54 & 318.15 & 1353.35 \\
\hline 40 & & 1394.87 & 1390.71 & 1386.57 & 1382.45 & 1378.35 & 328.15 & 1344.28 \\
\hline 50 & & 1401.03 & 1396.96 & 1392.91 & 1388.87 & 1384.86 & 338.15 & 1335.28 \\
\hline 60 & & 1406.95 & 1402.96 & 1398.98 & 1395.02 & 1391.08 & 348.15 & 1326.33 \\
\hline 70 & & 1412.65 & 1408.72 & 1404.82 & 1400.93 & 1397.06 & 358.15 & 1317.44 \\
\hline 80 & & 1418.14 & 1414.28 & 1410.44 & 1406.62 & 1402.81 & 363.15 & 1313.01 \\
\hline 90 & & 1423.44 & 1419.64 & 1415.86 & 1412.10 & 1408.36 & & \\
\hline 100 & & 1428.57 & 1424.83 & 1421.11 & 1417.40 & 1413.72 & & \\
\hline
\end{tabular}

* calculated from the following polynomials:

$\rho\left(\left[\mathrm{C}_{3} \mathrm{C}_{1} \mathrm{im}\right]\left[\mathrm{NTf}_{2}\right]\right)=1803.199-1.2132 \cdot T+3.7362 \cdot 10^{-4} \cdot T^{2}, \delta \rho=0.006 \mathrm{~kg} \cdot \mathrm{m}^{-3}$;

$\rho\left(\left[\mathrm{C}_{4} \mathrm{C}_{1} \mathrm{im}\right]\left[\mathrm{NTf}_{2}\right]\right)=1752.219-1.1584 \cdot T+3.3155 \cdot 10^{-4} \cdot T^{2}, \delta \rho=0.007 \mathrm{~kg} \cdot \mathrm{m}^{-3}$;

$\rho\left(\left[\mathrm{C}_{5} \mathrm{C}_{1} \mathrm{im}\right]\left[\mathrm{NTf}_{2}\right]\right)=1710.627-1.1283 \cdot T+3.1428 \cdot 10^{-4} \cdot T^{2}, \delta \rho=0.008 \mathrm{~kg} \cdot \mathrm{m}^{-3}$;

$\rho\left(\left[\mathrm{C}_{6} \mathrm{C}_{1} \mathrm{im}\right]\left[\mathrm{NTf}_{2}\right]\right)=1674.532-1.1086 \cdot T+3.1157 \cdot 10^{-4} \cdot T^{2}, \delta \rho=0.01 \mathrm{~kg} \cdot \mathrm{m}^{-3}$.

**experimental data; the standard uncertainties $u$ at atmospheric pressure are $u_{T}=0.05 \mathrm{~K}$ and $u_{p 0}=2 \mathrm{kPa}$, the expanded uncertainty ( $k=2$, level of confidence of 0.95$), U$, is $U(\rho)=1 \cdot 10^{-1}$ $\mathrm{kg} \cdot \mathrm{m}^{-3}$ 
Table 6. Calculated molar isobaric heat capacities of $\left[\mathrm{C}_{3} \mathrm{C}_{1} \mathrm{im}\right]\left[\mathrm{NTf}_{2}\right],\left[\mathrm{C}_{4} \mathrm{C}_{1} \mathrm{im}\right]\left[\mathrm{NTf}_{2}\right]$,

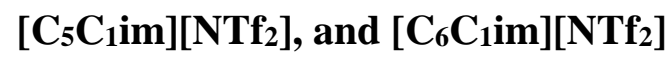

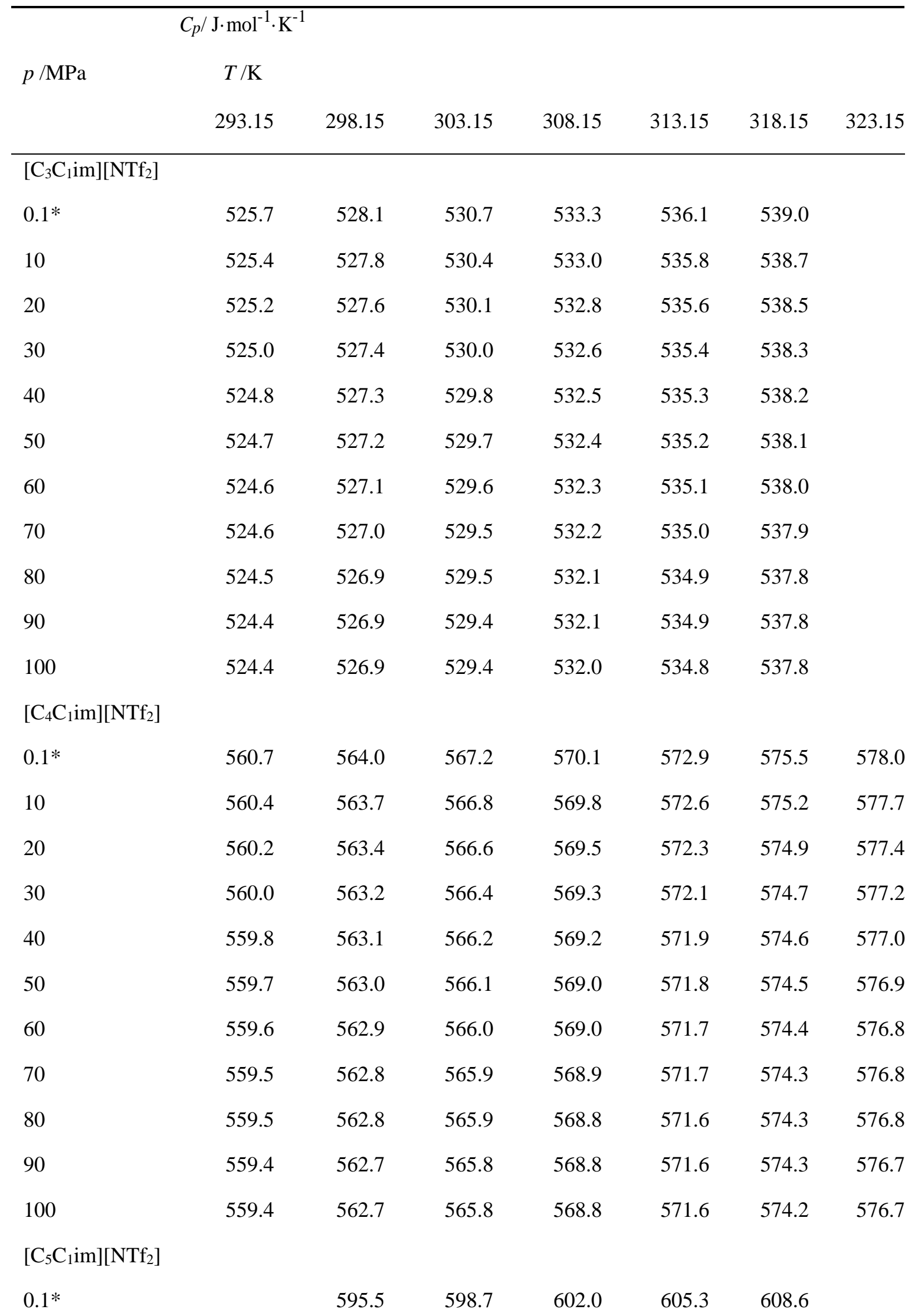




\begin{tabular}{|c|c|c|c|c|c|c|}
\hline 10 & 595.1 & 598.4 & 601.6 & 604.9 & 608.2 & \\
\hline 20 & 594.8 & 598.1 & 601.3 & 604.6 & 607.9 & \\
\hline 30 & 594.6 & 597.8 & 601.1 & 604.4 & 607.6 & \\
\hline 40 & 594.4 & 597.6 & 600.9 & 604.2 & 607.5 & \\
\hline 50 & 594.2 & 597.5 & 600.8 & 604.0 & 607.3 & \\
\hline 60 & 594.1 & 597.4 & 600.7 & 603.9 & 607.2 & \\
\hline 70 & 594.0 & 597.3 & 600.6 & 603.8 & 607.1 & \\
\hline 80 & 593.9 & 597.2 & 600.5 & 603.8 & 607.0 & \\
\hline 90 & 593.9 & 597.1 & 600.4 & 603.7 & 607.0 & \\
\hline 100 & 593.8 & 597.1 & 600.4 & 603.6 & 606.9 & \\
\hline \multicolumn{7}{|c|}{$\left[\mathrm{C}_{6} \mathrm{C}_{1} \mathrm{im}\right]\left[\mathrm{NTf}_{2}\right]$} \\
\hline $0.1^{*}$ & & 629.3 & 632.7 & 636.2 & 639.8 & 643.6 \\
\hline 10 & & 628.7 & 632.0 & 635.5 & 639.2 & 642.9 \\
\hline 20 & & 628.4 & 631.7 & 635.2 & 638.8 & 642.6 \\
\hline 30 & & 628.1 & 631.5 & 635.0 & 638.6 & 642.4 \\
\hline 40 & & 627.9 & 631.3 & 634.8 & 638.4 & 642.2 \\
\hline 50 & & 627.8 & 631.1 & 634.6 & 638.2 & 642.0 \\
\hline 60 & & 627.6 & 631.0 & 634.5 & 638.1 & 641.9 \\
\hline 70 & & 627.5 & 630.9 & 634.4 & 638.0 & 641.8 \\
\hline 80 & & 627.5 & 630.8 & 634.3 & 637.9 & 641.7 \\
\hline 90 & & 627.4 & 630.7 & 634.2 & 637.9 & 641.6 \\
\hline 100 & & 627.3 & 630.7 & 634.2 & 637.8 & 641.6 \\
\hline
\end{tabular}

* taken from ${ }^{45}$ 
Table 7. Calculated isentropic compressibilities of $\left[\mathrm{C}_{3} \mathrm{C}_{1} \mathrm{im}\right]\left[\mathrm{NTf}_{2}\right],\left[\mathrm{C}_{4} \mathrm{C}_{1} \mathrm{im}\right]\left[\mathrm{NTf}_{2}\right]$,

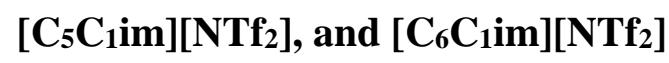

\begin{tabular}{|c|c|c|c|c|c|c|}
\hline \multirow{3}{*}{$p / \mathrm{MPa}$} & \multicolumn{3}{|c|}{$\kappa S \cdot 10^{10} / \mathrm{Pa}^{-1}$} & \multirow[b]{3}{*}{308.15} & \multirow[b]{3}{*}{313.15} & \multirow[b]{3}{*}{318.15} \\
\hline & $T / \mathrm{K}$ & & & & & \\
\hline & 293.15 & 298.15 & 303.15 & & & \\
\hline \multicolumn{7}{|c|}{$\left[\mathrm{C}_{3} \mathrm{C}_{1} \mathrm{im}\right]\left[\mathrm{NTf}_{2}\right]$} \\
\hline 0.1 & 4.3842 & 4.4797 & 4.5771 & 4.6762 & 4.7771 & 4.8799 \\
\hline 10 & 4.150 & 4.237 & 4.325 & 4.414 & 4.505 & 4.597 \\
\hline 20 & 3.942 & 4.021 & 4.101 & 4.182 & 4.264 & 4.347 \\
\hline 30 & 3.757 & 3.829 & 3.903 & 3.976 & 4.051 & 4.127 \\
\hline 40 & 3.592 & 3.659 & 3.726 & 3.793 & 3.862 & 3.931 \\
\hline 50 & 3.444 & 3.505 & 3.567 & 3.629 & 3.692 & 3.755 \\
\hline 60 & 3.310 & 3.366 & 3.424 & 3.481 & 3.539 & 3.597 \\
\hline 70 & 3.187 & 3.240 & 3.293 & 3.347 & 3.400 & 3.454 \\
\hline 80 & 3.076 & 3.125 & 3.175 & 3.224 & 3.274 & 3.324 \\
\hline 90 & 2.973 & 3.019 & 3.066 & 3.112 & 3.159 & 3.205 \\
\hline 100 & 2.878 & 2.922 & 2.965 & 3.009 & 3.053 & 3.096 \\
\hline
\end{tabular}

$\left[\mathrm{C}_{4} \mathrm{C}_{1} \mathrm{im}\right]\left[\mathrm{NTf}_{2}\right]$

$\begin{array}{lrrrrrrr}0.1 & 4.5334 & 4.6318 & 4.7322 & 4.8345 & 4.9387 & 5.0448 & 5.1529 \\ 10 & 4.280 & 4.368 & 4.458 & 4.549 & 4.641 & 4.734 & 4.830 \\ 20 & 4.058 & 4.137 & 4.218 & 4.299 & 4.382 & 4.465 & 4.550 \\ 30 & 3.862 & 3.934 & 4.008 & 4.081 & 4.156 & 4.231 & 4.307 \\ 40 & 3.688 & 3.755 & 3.821 & 3.889 & 3.957 & 4.025 & 4.094 \\ 50 & 3.532 & 3.593 & 3.655 & 3.717 & 3.779 & 3.842 & 3.905 \\ 60 & 3.392 & 3.448 & 3.505 & 3.562 & 3.620 & 3.677 & 3.735 \\ 70 & 3.264 & 3.316 & 3.369 & 3.422 & 3.475 & 3.529 & 3.582 \\ 80 & 3.147 & 3.196 & 3.245 & 3.295 & 3.344 & 3.394 & 3.443 \\ 90 & 3.039 & 3.086 & 3.132 & 3.178 & 3.224 & 3.270 & 3.317 \\ 100 & 2.940 & 2.984 & 3.027 & 3.071 & 3.114 & 3.157 & 3.200\end{array}$




$\begin{array}{lccccc}{\left[\mathrm{C}_{5} \mathrm{C}_{1} \mathrm{im}\right]\left[\mathrm{NTf}_{2}\right]} & & & & & \\ 0.1 & 4.7423 & 4.8467 & 4.9532 & 5.0618 & 5.1726 \\ 10 & 4.466 & 4.558 & 4.653 & 4.749 & 4.846 \\ 20 & 4.224 & 4.307 & 4.392 & 4.477 & 4.564 \\ 30 & 4.012 & 4.088 & 4.164 & 4.241 & 4.319 \\ 40 & 3.825 & 3.894 & 3.963 & 4.033 & 4.104 \\ 50 & 3.658 & 3.721 & 3.784 & 3.848 & 3.913 \\ 60 & 3.507 & 3.565 & 3.624 & 3.683 & 3.742 \\ 70 & 3.370 & 3.425 & 3.479 & 3.533 & 3.588 \\ 80 & 3.246 & 3.297 & 3.347 & 3.398 & 3.448 \\ 90 & 3.132 & 3.179 & 3.227 & 3.274 & 3.321 \\ 100 & 3.027 & 3.072 & 3.116 & 3.160 & 3.204\end{array}$

$\left[\mathrm{C}_{6} \mathrm{C}_{1} \mathrm{im}\right]\left[\mathrm{NTf}_{2}\right]$

$\begin{array}{lrrrrr}0.1 & 4.9611 & 5.0713 & 5.1838 & 5.2985 & 5.4155 \\ 10 & 4.658 & 4.755 & 4.853 & 4.953 & 5.055 \\ 20 & 4.395 & 4.481 & 4.569 & 4.657 & 4.747 \\ 30 & 4.167 & 4.244 & 4.323 & 4.402 & 4.482 \\ 40 & 3.966 & 4.036 & 4.107 & 4.179 & 4.251 \\ 50 & 3.787 & 3.851 & 3.916 & 3.982 & 4.048 \\ 60 & 3.626 & 3.686 & 3.745 & 3.805 & 3.866 \\ 70 & 3.481 & 3.536 & 3.591 & 3.647 & 3.702 \\ 80 & 3.349 & 3.400 & 3.451 & 3.503 & 3.555 \\ 90 & 3.228 & 3.275 & 3.323 & 3.372 & 3.420 \\ 100 & 3.116 & 3.161 & 3.206 & 3.251 & 3.296\end{array}$




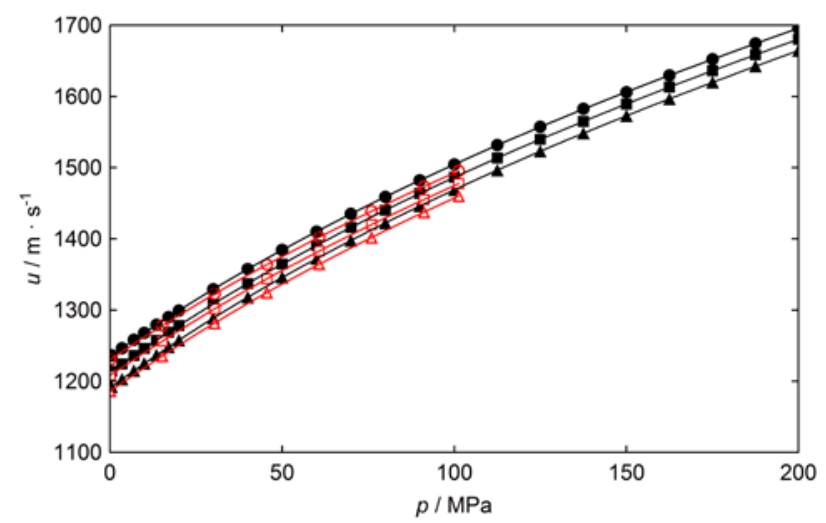

Figure 1a. Comparison of the speed of sound in $\left[\mathrm{C}_{3} \mathrm{C}_{1} \mathrm{im}\right]\left[\mathrm{NTf}_{2}\right]$ measured in this work (red open symbols) with the data of Esperança et al. ${ }^{9}$ (black symbols), $\mathbf{0}, 298.15 \mathrm{~K} ; \mathbf{\square}, 308.15$ $\mathrm{K} ; \boldsymbol{\Delta}, 318.15 \mathrm{~K} ;-$, calculated from empirical function: $u=\sum_{i=0}^{3} a_{i} p^{i}$.

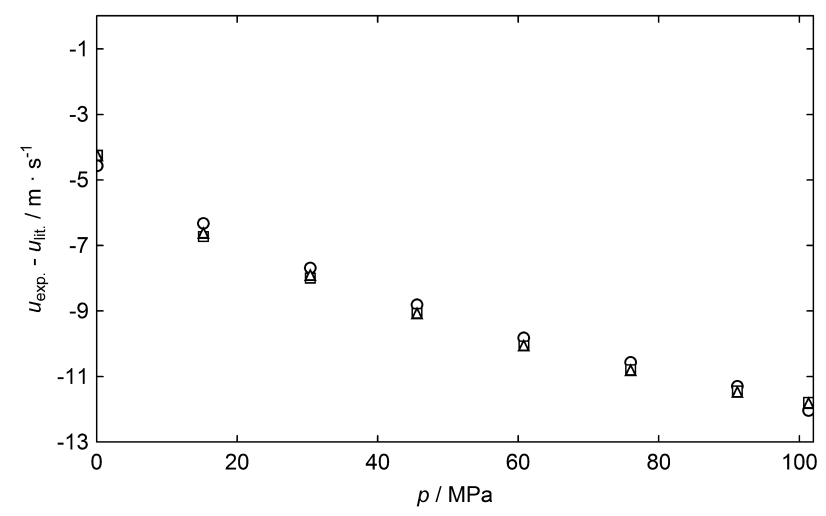

Figure 1b. Differences between speeds of sound in $\left[\mathrm{C}_{3} \mathrm{C}_{1} \mathrm{im}\right]\left[\mathrm{NTf}_{2}\right]$ reported in this work and literature data, O, $298.15 \mathrm{~K} ; \square, 308.15 \mathrm{~K} ; \triangle$, $318.15 \mathrm{~K}$. 


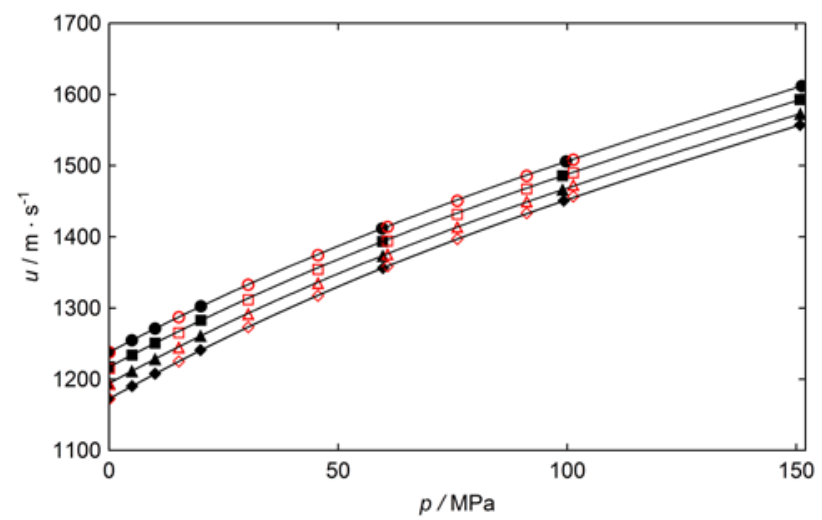

Figure 2a. Comparison of the speed of sound in $\left[\mathrm{C}_{4} \mathrm{C}_{1} \mathrm{im}\right]\left[\mathrm{NTf}_{2}\right]$ measured in this work (red open symbols) with reported by Gomes de Azevedo et al. ${ }^{10}$ (black symbols), @ $293.15 \mathrm{~K}$;

$\mathbf{\square}, 303.15 \mathrm{~K} ; \boldsymbol{\Delta}, 313.15 \mathrm{~K} ; \diamond, 323.15 \mathrm{~K} ;-\longrightarrow$, calculated from empirical function: $u=\sum_{i=0}^{3} a_{i} p^{i}$.

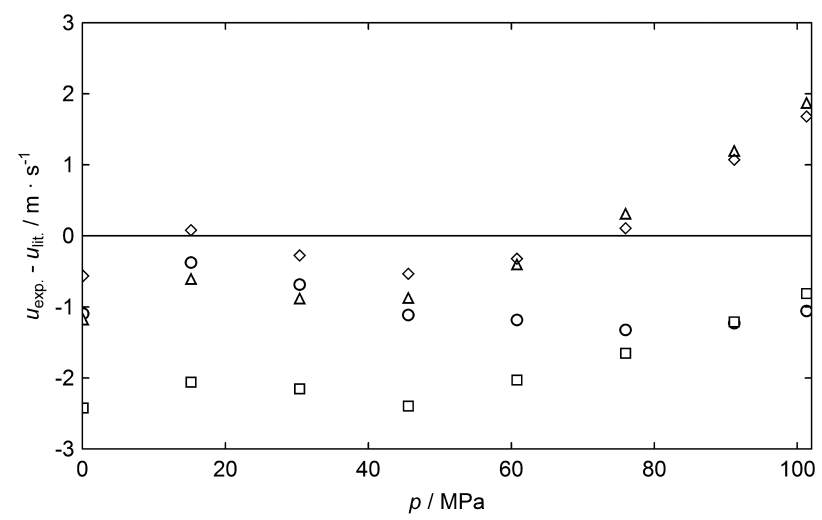

Figure 2b. Differences between speeds of sound in $\left[\mathrm{C}_{4} \mathrm{C}_{1} \mathrm{im}\right]\left[\mathrm{NTf}_{2}\right]$ reported in this work and literature data, $\bigcirc, 293.15 \mathrm{~K} ; \square, 303.15 \mathrm{~K} ; \triangle$, $313.15 \mathrm{~K} ; \diamond, 323.15 \mathrm{~K}$. 


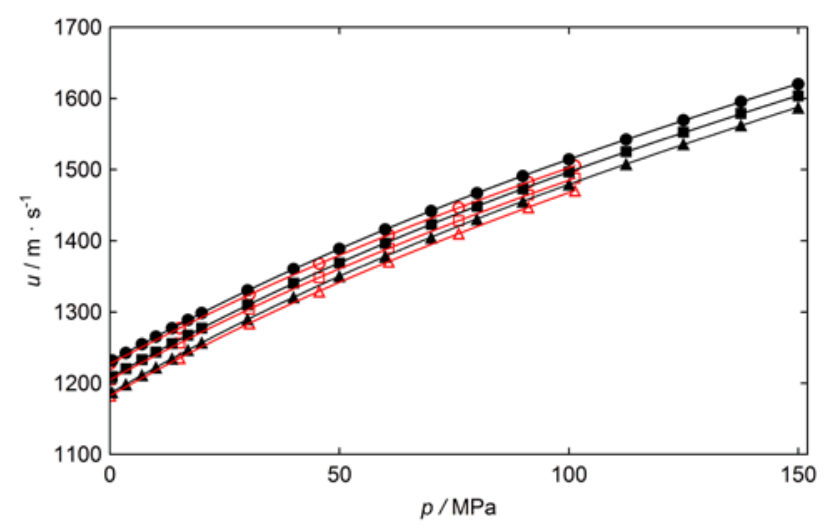

Figure 3a. Comparison of the speed of sound in $\left[\mathrm{C}_{5} \mathrm{C}_{1} \mathrm{im}\right]\left[\mathrm{NTf}_{2}\right]$ measured in this work (red open symbols) with reported by Esperança et al. ${ }^{9}$ (black symbols), @ , $298.15 \mathrm{~K}$; $\mathbf{\square}, 308.15$ $\mathrm{K} ; \boldsymbol{\Lambda}, 318.15 \mathrm{~K} ;-$, calculated from empirical function: $u=\sum_{i=0}^{3} a_{i} p^{i}$.

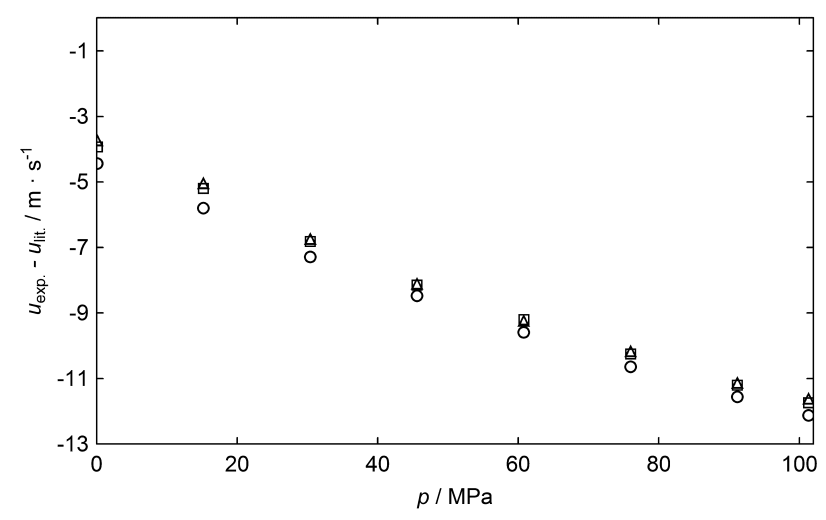

Figure 3b. Differences between speeds of sound in $\left[\mathrm{C}_{5} \mathrm{C}_{1} \mathrm{im}\right]\left[\mathrm{NTf}_{2}\right]$ reported in this work and literature data, $\bigcirc, 298.15 \mathrm{~K} ; \square, 308.15 \mathrm{~K} ; \triangle$, $318.15 \mathrm{~K}$. 


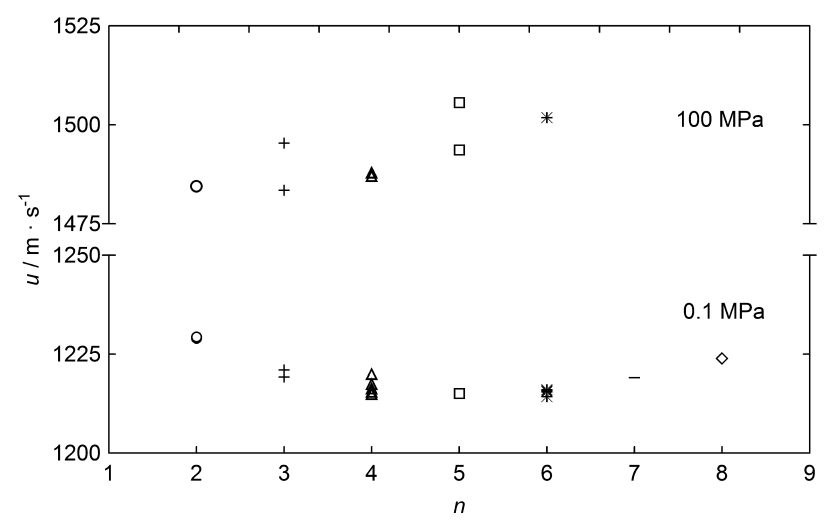

Figure 4. Influence of the chain length in the cation on the speed of sound in $\left[\mathrm{C}_{n} \mathrm{C}_{1} \mathrm{im}\right]\left[\mathrm{NTf}_{2}\right]$ at $303.15 \mathrm{~K}$ at $0.1 \mathrm{MPa}: \bigcirc, n=2^{8,20,34,35} ;+, n=3^{7,40} ; \triangle, n=4^{7,10,22,41,42} ; \square, n=5^{7} ; *, n=$ $6^{7,27,34,43} ;-, \quad n=7^{7} ; \diamond, n=8^{7}$ and at $100 \mathrm{MPa}: n=2^{7} ; n=3^{\text {this work,99} ; n=4^{\text {this work, } 10} ; n=5^{\text {this }}}$ work,9; $n=6^{\text {this work }}$.

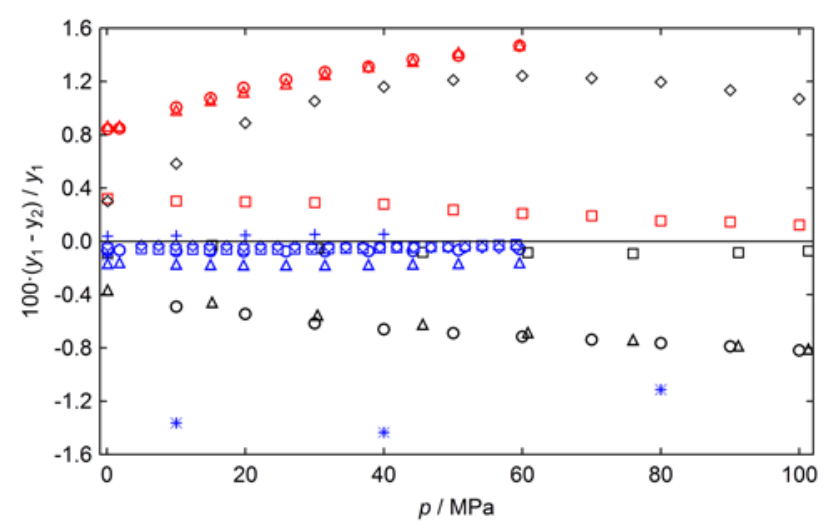

Figure 5. Fractional deviations of the speed of sound (black points), densities (blue points) and isentropic compressibilities (red points) obtained in this work $\left(y_{1}\right)$ from literature data $\left(y_{2}\right)$ for $\left[\mathrm{C}_{3} \mathrm{C}_{1} \mathrm{im}\right]\left[\mathrm{NTf}_{2}\right]\left(\mathrm{O}^{9}\right),\left[\mathrm{C}_{4} \mathrm{C}_{1} \mathrm{im}\right]\left[\mathrm{NTf}_{2}\right]\left(\square^{10}, \diamond^{12},{ }^{+46},{ }^{*}{ }^{47}\right),\left[\mathrm{C}_{5} \mathrm{C}_{1} \mathrm{im}\right]\left[\mathrm{NTf}_{2}\right]\left(\triangle^{9}\right)$ at $298.15 \mathrm{~K}$. 


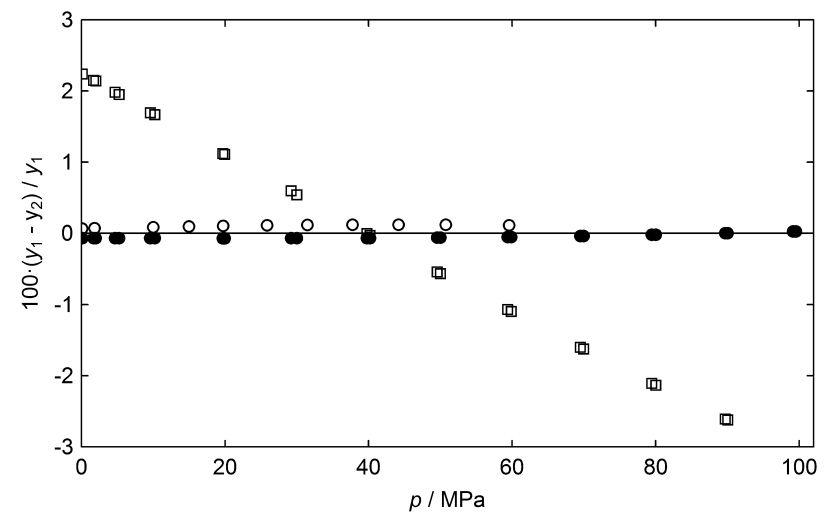

Figure 6. Fractional deviations of the speed of sound and density of $\left[\mathrm{C}_{6} \mathrm{C}_{1} \mathrm{im}\right]\left[\mathrm{NTf}_{2}\right]$ obtained in this work $\left(y_{1}\right)$ and literature data $\left(y_{2}\right)$ at $313.15 \mathrm{~K}$ for speed of sound $\left(\square^{13}\right)$ and for density $\left(\mathrm{O}^{10}, \mathrm{O}^{13}\right)$.

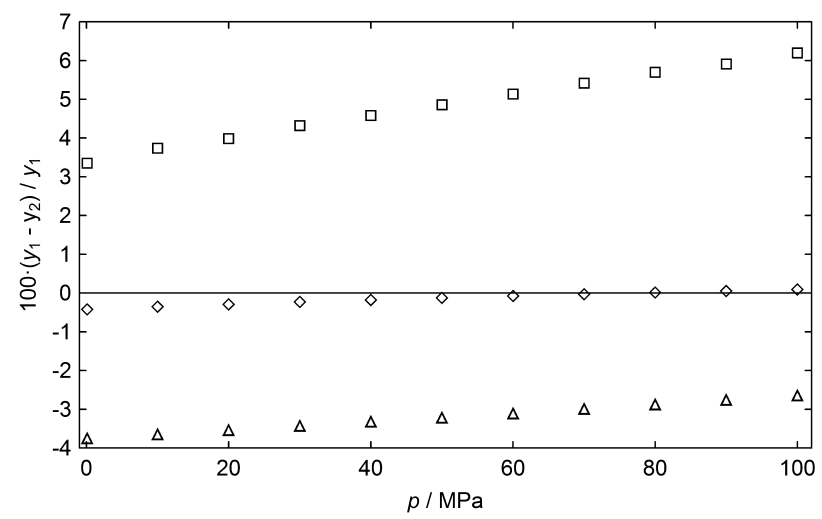

Figure 7. Fractional deviations of the isobaric heat capacities obtained in this work $\left(y_{1}\right)$ from literature data $\left(y_{2}\right)$ for $\left[\mathrm{C}_{4} \mathrm{C}_{1} \mathrm{im}\right]\left[\mathrm{NTf}_{2}\right]\left(\square^{10}, \diamond^{12}\right)$ at $298.15 \mathrm{~K}$ and for $\left[\mathrm{C}_{6} \mathrm{C}_{1} \mathrm{im}\right]\left[\mathrm{NTf}_{2}\right]\left(\triangle^{13}\right)$ at $313.15 \mathrm{~K}$. 